
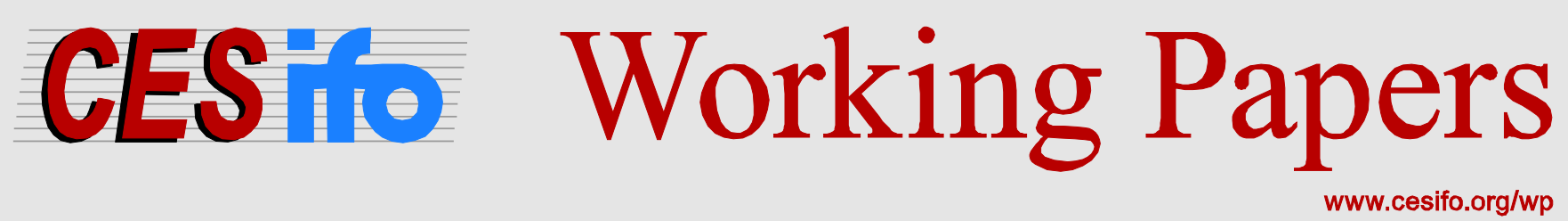

\title{
International Fiscal Policy Coordination and GDP Comovement
}

\author{
Nicholas Sly \\ Caroline Weber
}

CESIFO WORKING PAPER NO. 4358

Category 6: Fiscal Policy, Macroeconomics and Growth

August 2013

An electronic version of the paper may be downloaded

- from the SSRN website:

- from the RePEc website:

- from the CESifo website:

wWw.SSRN.com

www.RePEc.org

www.CESifo-group.org/wp

\section{CESifo}




\title{
International Fiscal Policy Coordination and GDP Comovement
}

\begin{abstract}
Economic shocks often permeate borders generating comovement in nations' business cycles over time. We highlight the fact that fiscal policy coordination is an important avenue by which national economies become more integrated, influencing the transmission of macroeconomic shocks between countries. We find that changes in fiscal policy coordination - as measured by the signing of a bilateral tax treaty - increase business cycle comovement by $1 / 2$ a standard deviation. This magnitude is one-and-a-half times larger than the effect of trade linkages, and is in sharp contrast to currency union membership, which has a near zero and statistically insignificant effect on business cycle comovement. We also find that new bilateral tax treaties increase comovement in shocks to nations' GDP trends, demonstrating the permanent effects of fiscal policy coordination.
\end{abstract}

JEL-Code: H870, F420, E620.

\author{
Nicholas Sly \\ University of Oregon \\ Department of Economics \\ USA - Eugene, OR 97403-1285 \\ sly@uoregon.edu
}

\author{
Caroline Weber \\ University of Oregon \\ Department of Economics \\ USA - Eugene, OR 97403-1285 \\ cweber5@uoregon.edu
}

July 2013

Much of the work on this project was conducted while Nicholas Sly was visiting CESifo, and he would like to thank the institute for its generous support. We would also like to thank Jeremy Piger for assistance at early stages. We have benefited from conversations with Steve Bond, Peter Egger, Jean Imbs, and Silvana Tenreyro, as well as seminar participants at Oxford University, CESifo and the Paris School of Economics. Thanks to Laura Kawano and Joel Slemrod for generously providing corporate tax rate data. Also, we wish to acknowledge the very capable research assistance provided by Erin Weld. All remaining errors are the responsibility of the authors. 


\section{Introduction}

Economic shocks often permeate borders generating comovement in nations' business cycles over time. For many countries, a significant portion of the fluctuations in their own GDP series are the result of shocks that originate abroad. ${ }^{1}$ Perhaps not surprisingly, comovement in output is known to be much stronger among countries with close economic ties. Here we highlight the fact that fiscal policy coordination between countries is an important avenue by which national economies become more integrated. Coordinated changes in tax rates, tax rules, and the tax base across countries can shift the incentives for firms to make real investments abroad, influence the location in which firms choose to report financial earnings, and even alter the incentives of workers to hold wealth or seek income opportunities in foreign countries. Recognizing the multitude of reasons that tax policy may influence economic ties between nations, our goal here is to examine how international fiscal policy coordination affects comovement between countries' GDP series.

Fiscal policy is not solely a domestic tool and international fiscal policy coordination is becoming increasingly important. For example, nations within the European Union coordinate rules for value added taxes on sales both within and outside member states. In 2012, nations within the G-20 entered the Convention on Mutual Administrative Assistance in Tax Matters, which allows for greater coordination on definitions of the tax base and enhanced cooperation on settling international disputes between tax jurisdictions. The 2013 meeting of the G8 in Ireland further emphasized these goals. Currently there are several bilateral tax agreements under negotiation among countries engaged in large volumes of foreign investment activity; for example, in early 2013, Brazil finally ratified a long stalled treaty with the US to allow for information exchange to prevent tax evasion, and in June 2012 Japan and the US formally entered negotiations to amend their current bilateral tax agreement. Similar efforts to coordinate fiscal policies are also arising in developing and transition economies. ${ }^{2}$ Each of these fiscal policies further integrates the national economies, potentially linking shocks to their output series over time.

\footnotetext{
${ }^{1}$ Kose, Prasad \& Terrones (2003) and Kose, Otrok \& Whiteman (2008) document evidence of substantial comovement in output fluctuations between countries, and show that a large fraction of the total variance in output over time is attributable to international business cycles.

${ }^{2}$ The governments of BRICS nations - Brazil, Russia, India, China and South Africa - announced in January 2013 a commitment to enhance coordination on definitions of the tax base, as well as double taxation issues for international earnings. This commitment was announced in the Delhi Communique following the summit between representatives from each government.
} 
One of the most common tools to coordinate tax policies across countries is a bilateral tax treaty (BTT). There are upwards of 2,500 tax treaties in force worldwide, including countries at various levels of development and from several regions of the world (Easson (2000)). These agreements cover a vast set of fiscal issues such as tax base definitions, international double taxation relief, and arbitration procedures. They are applicable to migrant workers, multinational corporations and financial institutions. Moreover, the specific provisions within BTTs across countries are relatively harmonized, as they typically conform to model treaties from the OECD or UN. Given the extent to which tax treaties are used as international policy instruments, their relevance for a wide range of economic activities, and their similarity in treatment across many countries, we focus our analysis of fiscal policy coordination on the impact that BTTs have on real GDP comovement over time.

The potential impact of fiscal policy coordination is difficult to predict a priori. BTTs synchronize several rules with regard to the determination of tax liabilities, and such synchronization may lead to more investment and production sharing between countries. As a result, countries may be more exposed to foreign shocks, and thereby realize greater comovement. ${ }^{3}$ Alternatively, fiscal coordination between countries could make domestic and foreign economic activities more substitutable, allowing productive resources to be more easily allocated to the domestic country if a negative shock occurs abroad, and visa versa. Thus, fiscal policy coordination may limit the exposure of national economies to foreign shocks, and thereby reduce comovement. ${ }^{4}$ Another possibility is that the principle impact of fiscal policy coordination may be to change where financial earnings/holdings are reported, rather than the location of real economic activities. Hence, one might anticipate little or no impact of the comovement of nations' real GDP series over time. The ubiquity of international fiscal coordination via BTTs, and the uncertainty about how such policies might influence output comovement across countries, motivate our study.

We exploit changes in tax policies over time that arise from new BTTs within a panel of 210 country-pairs over a thirty-year time period (1980-2010), and estimate their effects on GDP

\footnotetext{
${ }^{3}$ Burstein, Kurz \& Tesar (2008) explicitly model production sharing between countries with trade in complementarity inputs through vertical production networks, and show that such relationships indeed raise GDP comovement between nations. This fact is relevant here, given the evidence in Davies, Norback \& Tekin-Koru (2009) and Blonigen, Oldenski \& Sly (2012) that BTTs increase cross-border investment at the extensive margin, potentially increasing the degree of production sharing between countries.

${ }^{4}$ The canonical model of international real business cycles in Backus, Kehoe \& Kydland (1992) shows how a positive shock in one country raises output, and attracts investment from abroad. As a result, foreign GDP relatively declines as the home country absorbs greater investment which implies lower comovement at business cycle frequencies.
} 
comovement using both parametric and non-parametric techniques. Our parametric strategy estimates the effect of a new BTT on comovement using generalized estimating equations (GEE). The methodology builds from Papke \& Wooldridge (2008) and accounts for the fact that comovement is a bounded variable between -1 and 1 . We include correlated random effects, which allows us to control for unobserved time-invariant country-pair effects. This method is new to this literature and highly applicable whenever comovement is used as the dependent variable. ${ }^{5}$

Using the GEE strategy, we find that when a new BTT enters into force, it raises observed business cycle comovement by $1 / 2$ a standard deviation. By way of comparison, this effect of a new BTT on comovement is one-and-a-half times as large as a one standard deviation increase in trade linkages, and contrasts sharply with the lack of impact of currency union membership on cyclical comovement. ${ }^{6}$ We also find that BTTs have a positive impact on the comovement between shocks to the trend components of nations' GDP series, highlighting the permanent economic effects of fiscal policy coordination. While fiscal policy coordination impacts both cyclical and trend comovement, we find that the relevance of BTTs for the correlation in cyclical versus trend shocks differs across G7 membership. Country-pairs that include a G7 member exhibit significant increases in cyclical comovement following the signing of a new treaty, with no significant effect of BTTs on trend comovement. The opposite is true for pairs of countries that are both outside the G7, with fiscal policy having a significant impact only on trend comovment. ${ }^{7}$ Our results are robust to various measures of comovement periods (i.e., decade-long time windows, 8-year windows, or 12-year windows), the method used to extract the cyclical and trend components of nations' GDP series, other potentially confounding features of country-pairs, as well as pair- and period- specific fixed effects. We also show that accounting for the boundedness of comovement is particularly important when using commonly implemented band-pass filter techniques to extract cyclical components of nations' GDP series, due to the fact that measured comovement levels

\footnotetext{
${ }^{5}$ For example, identifying the determinants of comovement between output and government tax revenues is important in public finance literature, as the cyclicality of tax revenues can generate significant deadweight loss (see Seegert (2012) for example). In the finance literature, the comovement between stock exchanges across countries is of substantial interest (e.g., Karolyi \& Stulz (1996)), as is the well-known Fisher Effect, which describes comovement between asset returns and inflation (e.g., Boudoukh, Richardson \& Whitelaw (1994)). Also, a large macroeconomic literature is devoted to studying comovement between country aggregates besides output, such as consumption and investment.

${ }^{6}$ In a similar respect, Baxter \& Kouparitsas (2005) demonstrate that currency union membership does not have a robust impact on cyclical comovement once accounting for trade flows and other key country characteristics.

${ }^{7}$ Many previous studies have also found significant differences in comovement patterns within versus outside the G7; see for example Kose et al. (2003) and Kose et al. (2008).
} 
frequently lie near the upper bound.

As an alternative to our parametric method, we employ a non-parametric technique and estimate the kernel density of comovement relationships separately for observations in which a BTT is in force, or not in force across several time periods. One may be concerned that fiscal policy coordination matters only for countries that are observed to initially have positive levels of comovement. It may also be that that nations with negative prior levels of comovement have more strong negatively correlated business cycles after a BTT enters into force, such that the effects of BTTs are non-monotonic. This issue has important policy relevance as fiscal policy coordination is increasingly being applied across a broad set of countries. Our non-parametric strategy reveals that the entire distribution of observed correlations in output shocks shifts symmetrically in response to the signing of BTT. The increase in comovement is realized similarly for countries that have little prior comovement, and those nations that already have linked business cycles. Even nations which exhibit negative comovement prior to the signing of a BTT have less negatively correlated business cycles afterwards. In short, fiscal policy coordination appears to have a wide-reaching positive impact on GDP comovement.

In the next section, we discuss the literature related to comovement and the transmission of output shocks. Section 3 provides details about the empirical strategies we use to identify the impact of fiscal policy coordination. Section 4 discusses the methods we use to measure GDP comovement across countries, and lists data sources. In section 5 we present the the empirical results. The final section concludes.

\section{Literature}

As is common in the literature, we focus our analysis of the relationship between output shocks on the comovement in nations' GDP series, measured specifically as the correlation between the cyclical and trend components of their output series over time. While this measure is ubiquitous in studies of output shock transmission, we acknowledge that there are alternative measures/definitions of the relationship between national economies. One alternative is contagion, which measures changes in comovement patterns that occur as the result of some underlying economic shock. Besides the ambiguity surrounding the precise meaning of contagion (statistical or otherwise), there is an 
important difference in the question we examine: the literature on contagion focuses on how/if the correlation in output shocks between countries has changed over time, while our goal is to go further and investigate whether fiscal policy coordination is indeed a cause of such changes in the correlation of output shocks. ${ }^{8}$

Another possibility is a coincident index similar to that developed in Kim \& Nelson (1998), which allows comovement relationships between economic variables to vary with the phases of the business cycle. Besides the known difficulties in conducting inference when using a coincident index, this measure describes the relationship between aggregate variables that are subject to the same business cycle (i.e., aggregate variables within a particular country), and thus is inappropriate in the international setting which we are considering.

Finally, our study of comovement in nations' output series is distinct from convergence in real incomes across countries. While comovement focuses on the correlation in shocks - or changes - to real GDP across countries, the literature on convergence examines the rate at which real GDP per capita levels become more similar. For recent examples of studies of convergence see Barro (2012), Rodrik (2011), and Acemoglu (2009) for further discussion.

There is of course a large literature on the determinants of comovement in national outputs, as well as the time series properties of these relationships. We will discuss this literature below when describing our empirical strategy, as the results of these studies motivate the inclusion of several control variables in our empirical analysis.

Finally, we note that our analysis, which centers on how coordinated fiscal policy actions impact the relationship between output shocks across countries, is distinct from the literature on the transmission of fiscal shocks across borders. This literature focuses on how changes in government deficit spending or tax rates within one country may impact sovereign debt/spending abroad. The classic treatment of this issue is Frenkel \& Razin (1986), with more recent studies of the transmission of fiscal shocks available in Corsetti, Müller \& Sibert (2008) Corsetti, Kuester \& Muller (2011), and Feyrer \& Shambaugh (2012), among others. Likewise, our focus on output shocks in nations' GDP series is distinct from transmission of financial shocks, such that default in government bonds within one country leads to financial instability elsewhere; see for example Guerrieri, Iacoviello \& Minetti (2012) and Claessens \& Forbesi (2001).

\footnotetext{
${ }^{8}$ For a review of the literature on contagion see Forbes \& Gigobon (2002).
} 


\section{Empirical Strategy}

In this section, we describe our empirical strategies used to estimate the effect of international fiscal policy coordination on GDP comovement. Our baseline specification is the simple linear empirical model used throughout the comovement literature, which will allow us to readily compare the estimated effects of fiscal policy coordination in promoting comovement to other determinants identified in previous analyses. Second, we present the GEE empirical strategy that specifically accommodates the fact that BTTs must have non-linear effects because comovement is a bounded outcome. Third, we estimate the effects of fiscal policy coordination non-parametrically, and present kernel density estimates for observations that differ according to treaty status and time period.

\subsection{Baseline Model}

Our baseline specification is the standard model taken from the literature. Specifically, we estimate

$$
\rho_{i j T}=\alpha+\beta \text { Treaty }_{i j T}+X_{i j T} \Gamma+\phi_{T}+\psi_{i j}+\epsilon_{i j T}
$$

where $\rho_{i j T}$ is the correlation between shocks in the quarterly GDP series of countries $i$ and $j$ during time period $T$, the variable Treaty $_{i j T}$ is an indicator for whether the country-pair $i j$ has a BTT in force during period $T$, the vector $X_{i j T}$ is a set of control variables, $\phi_{T}$ is a period-specific effect, and the term $\psi_{i j}$ is a country-pair fixed effect. ${ }^{9}$ While the majority of the literature is focused solely on comovement of shocks at business cyclical frequencies, we present results for both the comovement of cyclical output and comovement of shocks to trend levels of output.

In addition to fiscal policy coordination, there are several cofactors that we wish to control for when identifying the effect of fiscal policy coordination. The set of control variables included in $X_{i j T}$ are drawn from the previous comovement literature. The seminal paper by Frankel \& Rose (1998) demonstrates that trade flows between countries are associated with greater degrees of GDP comovement. ${ }^{10}$ In addition to trade flows, Imbs \& Wacziarg (2003) demonstrate that

\footnotetext{
${ }^{9}$ For reasons we discuss in detail below, our preferred strategy is to define the comovement period, $T$, as a decadelong time span. This specification is consistent with prior literature, and regardless, we show that none of our results are sensitive to time window over which output correlations are calculated.

${ }^{10}$ The impact of trade on comovement has been shown to be robust to various potentially confounding factors, different specifications of fixed effects, and is even present for intra-national trade; see for example Baxter \& Kouparitsas (2005), Burstein, Kurz \& Tesar (2008), Levchenko \& di Giovanni (2010), Clark \& van Wincoop (2001) and
} 
the similarity in industry specialization across countries is associated with greater comovement. While our country-pair fixed effects partially capture such features, Imbs (2004) estimates a model with measures of differences in income to indicate potential synchronization between countries; we include this measure as well. Several studies, beginning with Rose \& Engel (2002), argue that nations within a currency union exhibit stronger comovement in cyclical output. We include an indicator variable, $C U_{i j T}$, that equals one if country-pair $i j$ belongs to a currency union during period $T$.

There is evidence of period-specific effects within comovement patterns in Kose, Otrok \& Whiteman (2008) and Kose, Otrok \& Prasad (2012), suggesting that the empirical model should include period-specific effects, $\phi_{T}$. Average levels of comovement typically vary across country-pairs; see Kose, Prasad \& Terrones (2003). Moreover, the propensity to sign a tax treaty can differ according to unobserved country-pair characteristics. ${ }^{11}$ For each of these reasons, we prefer specifications that include country-pair unobserved effects, $\psi_{i j}$.

\subsection{Generalized Estimating Equations}

The baseline model in equation (1) corresponds to the empirical strategy typically used when examining the determinants of business cycle comovement between countries. Hence, the baseline results allow us to readily compare the estimated effects of fiscal policy coordination to other factors identified in the literature. However, the linear model given by equation (1) fails to account for the fact that output comovement is bounded for any pair of countries, such that $\rho_{i j T} \in[-1,1]$. As a result, these estimates are, at best, a first-order approximation to the effect of signing a BTT.

To address this issue, we present an empirical strategy that builds from the GEE approach developed in Papke \& Wooldridge $(1996,2008)$. The first step is to transform measures of comovement into fractional response variables. Given that correlations in output shocks vary between -1 and 1, we perform the following transformation:

$$
\tilde{\rho}_{i j T}=\frac{\rho_{i j T}}{2}+\frac{1}{2}
$$

\footnotetext{
Blonigen, Piger \& Sly (2012).

${ }^{11}$ For example, Egger, Larch, Pfaffermayr \& Winner (2006) argue that fixed endowments (e.g., capital stocks) may influence the propensity for countries to sign BTTs.
} 
Note that if the correlation for a country-pair during any period is -1 , then $\tilde{\rho}_{i j T}=0$. Similarly, if the correlation for any country-pair during an period is 1 , then $\tilde{\rho}_{i j T}=1$. Moreover, $\tilde{\rho}_{i j T}$ varies continuously and monotonically according to $\rho_{i j T}$ within the unit interval.

We then estimate the effects of fiscal policy coordination on (the transformed fractional response measure of) comovement using generalized estimating equations. Specifically, we estimate

$$
\tilde{\rho}_{i j T}=\Phi\left(\beta \text { Treaty }_{i j T}+X_{i j T} \Gamma+\psi_{i j}\right)+\xi_{i j T}
$$

where $\Phi(\cdot)$ is the standard normal cumulative distribution function. Following Papke \& Wooldridge (2008) we make two standard assumptions regarding the distributions of the unobserved effects, $\psi_{i j}$. First, we assume that, conditional on $\psi_{i j}$, the regressors Treaty ${ }_{i j T}$ and $X_{i j T}$ are strictly exogenous. This does not, however, rule out the possibility that treaty status may be correlated with unobserved country-pair effects. Instead, we only require that, conditional on pair-specific effects, our key regressors are uncorrelated with $\xi_{i j T}$.

Second, to obtain estimates of the average partial effect of BTTs, we need to specify the distribution function for the unobserved effects. Again following the approach in Papke \& Wooldridge (2008), we employ a Chamberlain-Mundlak device, and impose a conditional normality assumption. ${ }^{12}$ Specifically, the conditional distribution of the unobserved country-pair effects satisfies

$$
\psi_{i j} \mid\left(\operatorname{Treaty}_{i j T}, X_{i j T}\right) \forall T \sim \operatorname{Normal}\left(\theta+\bar{X}_{i j}, \sigma^{2} \exp \left(\bar{X}_{i j} \lambda\right)\right)
$$

where $\bar{X}_{i j}$ is a vector of time averages of all covariates, $X_{i j T}$, within each country-pair. Specifying the standard error structure in this way allows for heteroskedasticity across country-pairs. This method is referred to in the literature as correlated random effects. Note that in a linear panel setting, fixed effects and correlated random effects yield the same estimates (Wooldridge, 2010). Here, in this non-linear panel setting, using GEE with correlated random effects instead of a fixed effects fractional logit or probit model allows us to avoid the incidental parameters problem that commonly plagues estimation of non-linear fixed effects models (Papke \& Wooldridge, 2008).

We could also include the time average of treaty status within a country-pair, $\overline{\text { Treaty }}_{i j}$, into

\footnotetext{
${ }^{12}$ See also Mundlak (1978) and Chamberlain (1980).
} 
the specification of the unobserved effects in (4). This might be important if the time at which countries signed new BTTs were correlated with their typical levels of comovement. We note however, that because over our sample BTTs are introduced and not eliminated within countrypairs, there is a strong mechanical multicollinearity between Treaty ${ }_{i j T}$ and $\overline{\text { Treaty }}_{i j}$. Given this artificial multicollinearity that is generated by the inclusion of $\overline{\text { Treaty }}_{i j}$ our preference is to omit it; regardless, we show below that our results are insensitive to whether or not the time average of treaty status is included, suggesting that unobserved differences in comovement levels between countries are uncorrelated with the timing of their BTT signing.

\subsection{Non-Parametric Estimation}

The GEE strategy described in the last section has several advantages over the baseline linear model in (1). It does however impose a specific functional form on the conditional expectation of comovement on the measure of fiscal policy coordination (i.e., the standard normal). More importantly, the results of the parametric strategy may not fully reveal important heterogeneity, or even mask non-monotonicities in the effects of BTTs. For example, while countries in our sample exhibit positive comovement on average, there are several country-pairs and time periods for which we observe negative comovement. It is plausible that country-pairs that comove negatively prior to a BTT exhibit more negative comovement afterwards, while countries with positive comovement exhibit more positive comovement after the treaty enters into force. To address such concerns, we estimate kernel densities of observed comovement by treaty status for all country-pairs who signed a treaty during 1980-2010 are included in this analysis. ${ }^{13}$ Considering the entire distribution of comovement relationships across treaty status and time ensures that the estimated effects of BTTs are not driven by few outliers, and are in fact realized for countries with any degree of prior comovement. All of our estimates are obtained using an optimal bandwidth and the Epanechnikov kernel. We obtain similar results with more narrow definitions of bandwidth, and if we employ other common kernels. To evaluate the role of fiscal policy coordination, we calculate Kolmogorov-Smirnov statistics to examine whether the conditional density functions of comovement relationships differ according to treaty status.

\footnotetext{
${ }^{13}$ We consider a treaty in force between a country-pair $i j$ during the decade denoted by $T$ if the treaty is in force for half of the years $t \in T$. See the next section for more discussion about the measurement of comovement, and specifically the choice of decade-long time periods.
} 


\section{Data and Measurement}

Measuring comovement between countries requires information about GDP series across countries, which we take from the International Financial Statistics, made available by the IMF. For 21 countries, we observe real quarterly output from 1980:Q1 to 2010:Q4. The set of countries in our sample corresponds to those studied extensively in previous analyses of comovement. ${ }^{14}$ By restricting ourselves to the post-1980 period we are able to observe quarterly fluctuations in output (as opposed to lower frequency annual GDP data) for a large set of country-pairs. ${ }^{15}$ The high frequency at which we observe GDP levels is important given the short duration of many business cycle shocks; for example, annual data will average away business cycle episodes lasting only a few quarters.

From the real GDP series for each country, we must estimate business cycle shocks and shocks to output trends for each country; the correlation in these shocks represents the level of comovement for any country-pair. The existing literature that examines comovement has taken multiple approaches to measure the business cycle component of real GDP, including deterministic detrending (linear or quadratic), the band-pass filters of Hodrick \& Prescott (1997) and Baxter \& King (1999), and statistical models that specify separately the distinct trend and cyclical components of real GDP. Deterministic detrending methods, which appeared early in the literature, are unnecessarily $a d$ hoc, and do not flexibly allow country-specific trends to shift during the sample period. Measures of business cycle shocks obtained from band-pass filters can also be problematic, given that they are particularly sensitive to the presence of unit-roots in countries' output series. ${ }^{16}$ Band-pass filters also require that we arbitrarily specify the frequency domain in which cyclical shocks occur. Generally, we are agnostic about which method should be used to measure business cycle shocks, and hence comovement between country-pairs. ${ }^{17}$ We note that (as discussed in detail in Section

\footnotetext{
${ }^{14}$ The countries in our sample are Australia, Austria, Belgium, Canada, Denmark, Finland, France, Germany, Italy, Japan, Korea, Mexico, Netherlands, New Zealand, Norway, Portugal, Spain, Sweden, Switzerland, United Kingdom and United States.

${ }^{15}$ New Zealand is a slight exception in that we do not observe the real GDP series until mid 1982.

${ }^{16}$ When real GDP contains a unit root, band-pass filters will both produce a measure of the cyclical component that is partially influenced by shocks to the stochastic trend. As an example of this, Cogley \& Nason (1995) and Murray (2003) demonstrate that if real GDP is itself a random walk, band-pass filters will generate a cyclical component. In the literature, this phenomenon is commonly known as a "spurious cycle." See, e.g., Cogley (2001) and Pedersen (2001).

${ }^{17}$ Similarly, common band-pass filters to not explicitly characterize the trend component of nations' GDP series. Since we are also interested in comovement in trend shocks, the explicit characterization of both the trend and cyclical components of GDP in the UC model is particularly advantageous.
} 
5.5.2 below) all of our results are maintained if we adopt measures of comovement constructed from estimates obtained from standard band-pass filters. Yet given the limitations discussed above, we use measures of comovement obtained by estimating the business cycle and trend components in real GDP using an unobserved-components (UC) model.

The UC model has a long history in macroeconometrics as a tool for business cycle measurement. ${ }^{18}$ Specifically, the UC framework divides, log real GDP for country $i$ at date $t$, denoted $y_{i, t}$, additively into trend $\left(\tau_{i, t}\right)$ and cyclical $\left(c_{i, t}\right)$ components:

$$
y_{i, t}=\tau_{i, t}+c_{i, t}
$$

The trend component is specified as a random walk process, while the cyclical component follows a covariance stationary autoregressive (AR) process:

$$
\begin{gathered}
\tau_{i, t}=\mu_{i}+\tau_{i, t-1}+v_{i, t}, \\
\phi_{i}(L) c_{i, t}=\epsilon_{i, t},
\end{gathered}
$$

where $\phi_{i}(L)$ is a $p^{t h}$ order lag polynomial with all roots outside the complex unit circle, $v_{i, t} \sim$ i.i.d. $N\left(0, \sigma_{v_{i}}^{2}\right)$, and $\epsilon_{i, t} \sim$ i.i.d. $N\left(0, \sigma_{\epsilon_{i}}^{2}\right) \cdot{ }^{19}$

Consistent with the existing literature on business cycle measurement with UC models, we make the assumption of independence between trend and cyclical shocks, such that $\sigma_{v_{i}, \epsilon_{i}}=0 .{ }^{20}$ The model in (5) is estimated via maximum likelihood, and estimates of the unobserved trend and cycle components are constructed using the Kalman Filter. ${ }^{21}$

\footnotetext{
${ }^{18}$ Early examples of macroeconomic detrending using the UC framework include Harvey (1985), Watson (1986), and Clark (1987).

${ }^{19}$ The UC model identifies trend versus business cycle fluctuations by specifying the trend as the accumulation of permanent effects of shocks to the level of real GDP; i.e., the trend in real GDP is equivalent to its stochastic trend. The business cycle component is transitory fluctuations in the real GDP series, measured as the deviation from the stochastic trend. This identification strategy is consistent with a wide range of macroeconomic models in which business cycle variation represents temporary fluctuations in real GDP away from trend. As shown in Morley, Nelson \& Zivot (2003), the UC approach to detrending is also equivalent to the well-known Beveridge \& Nelson (1981) decomposition, which measures the business cycle from the forecastable variation in real GDP growth. Specifically, Morley, Nelson \& Zivot (2003) show that given the same reduced-form time-series model used to represent real GDP, the UC-based decomposition gives the same estimates of trend and cycle as the Beveridge-Nelson decomposition. Rotemberg \& Woodford (1996) argue that this forecastable variation makes up the essence of what it means for a macroeconomic variable to be "cyclical."

${ }^{20}$ See, e.g., Harvey (1985), Clark (1987) and Harvey \& Jaeger (1993). Morley, Nelson \& Zivot (2003) provide analysis and application of UC models with correlated components.

${ }^{21}$ The AR model for the trend component described above implies a constant average growth rate of for the trend
} 
Finally, for each country-pair in our sample, we measure comovement as the correlation in the cyclical fluctuations in outputs obtained from the estimates in equation (5). The correlation between cyclical fluctuations in countries $i$ and $j$ over period $T$ is given by:

$$
\rho_{i j T}^{c}=\operatorname{corr}_{T}\left(\widehat{c}_{i, t}, \widehat{c}_{j, t}\right)
$$

where $\operatorname{corr}_{T}(\cdot)$ indicates the sample correlation coefficient measured using data during period $T$, and $\widehat{c}_{i, t}$ and $\widehat{c}_{j, t}$ represent the Kalman filtered estimates of the business cycle component for countries $i$ and $j$ respectively.

There is substantial evidence in the existing literature that both the business cycle and trend components account for a substantial portion of quarterly fluctuations in international real GDP growth series; see, e.g., Cogley (1990), Morley, Nelson \& Zivot (2003), and Aguiar \& Gopinath (2007). Furthermore, Blonigen, Piger \& Sly (2012) demonstrates that comovement in trends versus cycles can have opposite relationships with key country-pair characteristics. Thus we are also concerned with how fiscal policy coordination influences comovement in shocks to nations' output trends. The correlation between trend shocks in countries $i$ and $j$ over period $T$ is given by:

$$
\rho_{i j d}^{\tau}=\operatorname{corr}_{d}\left(\widehat{v}_{i, t}, \widehat{v}_{j, t}\right)
$$

where $\widehat{v}_{i, t}$ and $\widehat{v}_{j, t}$ represent the Kalman filtered estimates of the shocks to the trend component for countries $i$ and $j$.

The inclusion of country-pair effects into empirical models implies that we identify the effects of BTTs by changes in comovement relationships within countries that switch treaty status. While specifying the model in this manner assuages some endogeneity concerns regarding treaty status across countries, it does raise issues with regard to specifying the period $T$ over which output correlations are measured. Consider two sets of country-pairs $i j$ and $k l$ for which we observe a new BTT signed during the sample period, but the date the treaties enter into force is different. The

component of real GDP. Generally, we relax this restriction, and for each country estimate a version of the AR model in which allows specifically for structural breaks in the series over time. This break date is estimated along with the other parameters of the model via maximum likelihood, assuming that the break date does not occur in the initial or terminal $20 \%$ of the sample period. We select the estimates for each country by choosing the model that minimizes the Schwarz Information Criterion. 
length of the pre-treaty period for country-pair $i j$ is not the same for pre-treaty period for pair $k l$, and likewise for the respective post-treaty periods. Hence, taking the naive approach of defining $T$ according to pre- and post- treaty periods would confound the empirical analysis by defining the BTT treatment asymmetrically across different country pairs. Moreover, countries that do not sign a new treaty during the sample period would have only one observation, while those that signed a treaty would have two observations. Neither of these features of the pre/post treaty definition of the comovement period are appropriate.

Our approach to defining comovement periods, $T$, is to select a period of time over which output correlations are calculated symmetrically across all country-pairs in the sample. Specifically, we set $T$ to be a decade, which in our sample generates three observed time periods within each countrypair (1980:Q1-1989:Q4, 1990:Q1-1999:Q4, and 2000:Q1-2010:Q4), and yields a balanced panel. In addition to the benefits of having a symmetric definition of comovement periods across country-pair observations, defining time periods in this manner is advantageous in that it allows us to control for period-specific effects, $\phi_{T}$, that absorb common shocks realized across countries that we would not want to spuriously attribute to transmission of shocks between countries.

There are several reasons to consider a decade-long time period. First, this time interval matches the earlier literature on GDP comovement, which aids comparability of our results. ${ }^{22}$ Second, Doyle \& Faust (2005) find structural breaks in time-series processes for international real GDP series that correspond roughly to traditional decade definitions. Thus, the decade-long period is plausibly the maximum length for which one can compute correlations without contamination from structural breaks. Finally, shorter time spans limit the number of observations available to estimate the underlying comovement relationship between countries; such error in estimating the typical correlation between output shocks (our dependent variable) will attenuate the estimated effects of BTTs, biasing the impact of fiscal policy coordination toward zero. Although the decade-long span is preferable, we will also present estimates using comovement observed across a 8-year window and a 12-year window to verify that our results are not due to the selection of the comovement timeperiod. Table 1 provides the average decade-long comovement across all decades and country-pairs: average cyclical comovement is 0.248 and average trend comovement is 0.211 .

\footnotetext{
${ }^{22}$ See for example Frankel \& Rose (1998), Calderon, Chong \& Stein (2007), Kose, Prasad \& Terrones (2003) and Blonigen, Piger \& Sly (2012).
} 


\section{Table 1: Summary Statistics}

\begin{tabular}{lcc}
\hline \multicolumn{1}{c}{ Variable } & Mean & Std. Dev. \\
\hline$\rho_{\text {cycle } U C}$ & 0.248 & 0.416 \\
$\tilde{\rho}_{\text {cycle } U C}$ & 0.624 & 0.208 \\
$\rho_{\text {cycle } H P}$ & 0.360 & 0.370 \\
$\tilde{\rho}_{\text {cycle } H P}$ & 0.680 & 0.185 \\
$\rho_{\text {trend }, U C}$ & 0.211 & 0.242 \\
$\tilde{\rho}_{\text {trend }, U C}$ & 0.606 & 0.121 \\
Treaty & 0.860 & 0.315 \\
Trade & 0.223 & 0.525 \\
GDP Per Capita Diffs & 0.063 & 0.075 \\
Corporate Tax Rate Diffs & 7.607 & 7.744 \\
Currency Union & 0.044 & 0.206 \\
G7 & 0.567 & 0.496 \\
Bilateral Investment Treaty & 0.055 & 0.214 \\
Free Trade Agreement & 0.037 & 0.182 \\
EU Customs Union & 0.433 & 0.496 \\
Observations & 630 & \\
\hline
\end{tabular}


Treaty status for each country-pair is taken from the actual treaty documents available in the International Bureau of Fiscal Documentation. As is standard when examining BTTs, we define treaty status based on the in force date, not the date that the treaty is signed; the signature dates of treaties are typically several year prior to their entry into force, due to institutional delays surrounding the ratification of the treaty by each country. Once a treaty is signed, it must then be ratified by the governments of both countries, and then subsequently put into effect under law. Table 8 lists all the treaties between country-pairs that entered into force in our data set. There were 36 treaties signed in the 1980's, 24 treaties signed in the 1990's and 11 treaties signed in the 2000's. Each treaty may have been in force for only part of the decade over which comovement is constructed, so we use the average treaty status over the decade (e.g., Treaty is 0.8 if the treaty is in force for 8 out of the 10 years in the decade under consideration). ${ }^{23}$ The second panel of Table 1 lists the average balanced-panel fraction of treaties in force across all decades and country-pairs as 0.860 ; that is, the fraction of treaties in force in an average country-pair-decade is 0.860 .

Information about bilateral trade flows come from the Direction of Trade Statistics reported by the IMF. We observe total imports and exports between country-pairs. Trade flows are expressed in real US dollars. As is standard in the comovement literature, we divide real trade flows by the sum of countries' GDP, so that the trade variable can be interpreted as a measure of openness. We divide the trade variable by 100 to improve exposition of tables that report point estimates for the effects of trade on comovement patterns.

Population data also come from the International Financial Statistics database which, combined with GDP data, provide us with a measure of GDP per capita. ${ }^{24}$ Both GDP and population are indexed so that they equal one in 2005:Q1. From this, we construct the absolute value of the average GDP per capita difference between each country and its partner across each decade.

We use top marginal federal statutory corporate tax rate data from Kawano \& Slemrod (2012), which comes from the University of Michigan World Tax Database for years 1980-2002, and the OECD Tax Database for years 2003-2008. From this, we construct the absolute value of the average corporate tax rate difference between each country and its partner across each decade (or pre-post period). The average balanced-panel level of this variable is 7.607, as listed in the second-panel

\footnotetext{
${ }^{23}$ Our results are almost identical quantitatively if we try other reasonable measures of treaty status, such as an indicator that is one if the treaty was in place more than five years and zero if it was in place for less.

${ }^{24}$ Note that population data for each country are available only at the annual level.
} 
of Table 1. This means that the average (across all decades and country pairs) corporate tax rate difference between a country and its partner is 7.607 percentage points.

\section{Results}

In this section, we discuss the estimated effects of fiscal policy on output comovement obtained from each of our empirical strategies. Before turning to the regression results, it is worthwhile to discuss the properties of observed correlations in output shocks across our sample. Figure 1 plots the average decade-long comovement in cyclical and trend shocks to GDP across all country-pairs by quarter. For example, the comovement plotted for the first quarter of 1982 is the comovement from the first quarter of 1982 to the first quarter of 1992.

Cyclical comovement patterns exhibit a stark U-shape over the 30 year sample period. The steady decline in the average cyclical comovement prior to the 2000s is consistent with the evidence in Doyle \& Faust (2005), while the sharp increase in average comovement in the latter part of the corresponds with the global recession beginning in 2008. The U-shape pattern in cyclical comovement mitigates concerns about spurious results due to prior trends, where the incidence of BTTs has been rising steadily over time and the average differences in corporate tax rates have been falling steadily over time.

Prior to 1998, average level of trend comovement is flat. After 1998, the decade-long correlation in output includes observations from the latest global recession. As a result there is a sharp increase in average trend comovement in the latter part of the sample. Again, the flat level of trend comovement in the early part of the sample assuages concerns about obtaining spurious estimates. When estimating the effects of fiscal policy coordination on comovement below we are careful to control for the global recession period at the end of our sample.

\subsection{Results from Baseline Model}

Table 2 examines the effect of a treaty on cyclical comovement by estimating our baseline specification as laid out in equation (1). This specification corresponds to prior studies of the determinants of comovement. The standard errors in Table 2, and all other estimates in the paper, allow for 
Figure 1: Rolling 10-Year Comovement by Quarter

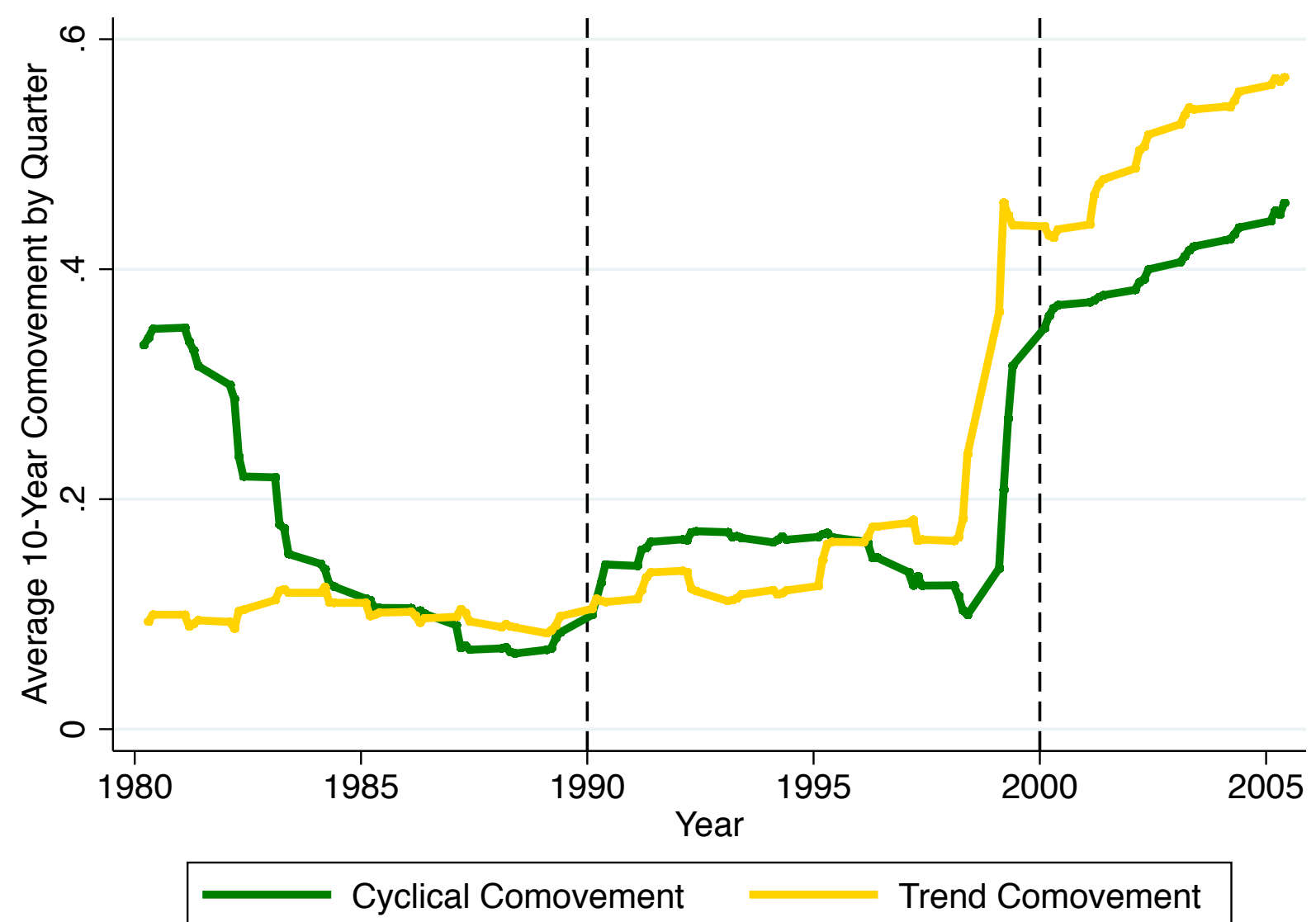

This figure plots the average decade-long comovement in cyclical and trend shocks to GDP across all country-pairs by quarter. For example, the comovement plotted for the first quarter of 1982 is the comovement from the first quarter of 1982 to the first quarter of 1992. 
heteroskedasticity and are clustered at the country-pair level. ${ }^{25}$

Column (1) includes only decade fixed-effects and the covariate of interest - Treaty. It does not include country-pair fixed effects. The coefficient on Treaty is 0.277 and is significant at the one percent level. This means that signing a new BTT raises the correlation between the two countries' GDP series by 0.666 of a standard deviation in observed business cycle comovement. When covariates are added in Columns (2) and (3), the estimated effect of a BTT declines by about one-third. When fixed effects are included in Columns (4)-(6), the estimated effect of a BTT remains approximately the same as in Columns (2) and (3), although the standard errors almost double. The stability of the estimated impact of BTTs across specifications further assuages concerns that the signing of a BTT is endogenous to particular countries or periods in the sample.

The estimates in Column (5), which includes all covariates as well as country-pair and decade fixed effects across the entire sample period, are our preferred estimates in this linear response framework. The Treaty coefficient is 0.206 and is significant at the five percent level. This means that signing a new BTT raises the correlation between the two countries' GDP series by approximately $1 / 2$ of a standard deviation (0.495) in observed business cycle comovement. Column (6) provides an additional robustness check by excluding the 2000-2010 decade (and thus the global recession), and the estimated effect of fiscal policy coordination remains the qualitatively similar: 0.230 without $2000 \mathrm{~s}$ as compared to 0.206 when looking across the whole sample. Given the lack of significance of the 2000's fixed effect, it is not surprising that the estimates are highly insensitive to this exclusion.

The estimated effects of our control variables correspond to the results obtained in previous analyses. Differences in GDP per capita, which capture differences in the patterns of industry specialization between countries, are associated with lower comovement, consistent with the evidence in Imbs (2004) and Imbs \& Wacziarg (2003). The coefficient on the G7 indicator suggests that there are higher average levels of comovement among member nations, consistent with the evidence in Kose, Prasad \& Terrones (2003). Although there is a robust estimated effect of G7 membership, we prefer to allow for more general differences in comovement levels among countries, and include

\footnotetext{
${ }^{25}$ One might argue that the standard errors should be clustered at a more disaggregated level than country-pair because there may be intra-cluster correlation. However, clustering on the country-pair is likely appropriate given the plausible serial correlation in comovement within a country-pair across decades. Regardless, the standard errors that cluster on the country-pair are more conservative, and so we report those.
} 
country-pair fixed effects, which subsume the G7 indicator variable.

Trade linkages are known to be associated with greater comovement, as first documented by Frankel \& Rose (1998). Consistent with previous work, in Columns (2) and (3) we find that countries that trade more intensively indeed exhibit greater levels of comovement. In the linear model, the role of trade linkages appears insignificant in Column (4) when country-pair fixed effects are included. However once we also control for time period specific effects in Column (5) - our preferred specification - we again confirm the stylized fact that trade has a significant positive effect on business cycle comovement. Table 2 also reports a positive estimated effect of currency union membership without country-pair effects (as in Rose \& Engel (2002)); yet once we control for fixed gravity variables using country-pair effects, currency union membership has a negative and only marginally significant effect on comovement (as shown by Baxter \& Kouparitsas (2005)). We also find that differences in corporate tax rates positively impact comovement between countries' aggregate output once country-pair fixed effects are included. Intuitively, differences in tax rates induce multinational firms to invest abroad, increasing the exposure of the domestic economy to foreign shocks. ${ }^{26}$

\subsection{Results from GEE Model}

Table 3 examines the effect of a treaty on cyclical comovement by estimating the GEE specification as laid out in equation (3). This model addresses the fact that the dependent variable - comovement - is bounded between -1 and 1 . We begin by examining the same variant specifications considered in our baseline linear model. The values reported in Table 3 are the estimated average partial effects, and the standard errors are again clustered at the country-pair level. Column (5) in Table 3 is directly comparable to our preferred estimate from Table 3: the corresponding estimate of the effect of signing a BTT from the GEE strategy implies that that signing a new BTT raises the correlation between the two countries' GDP series by 0.476 of a standard deviation in observed business cycle comovement, which is remarkably similar to our preferred estimate in the linear model (0.495), suggesting that the boundedness of the outcome variable does not significantly bias the estimates for Treaty in the linear model.

\footnotetext{
${ }^{26}$ Kleinert, Martin \& Toubal (2012) provide direct evidence that the presence of foreign multinationals indeed raises domestic comovement with their countries of origin. Burstein, Kurz \& Tesar (2008) also show that greater production sharing between countries leads to greater business cycle comovement.
} 
Note that Columns (4)-(8) of Table 4 estimate the GEE model with correlated random effects for unobserved country-pair characteristics, which is implemented according to equation (4) by the inclusion of time averages of all covariates. In Columns (4)-(5) we include the time average observation for treaty status $\overline{\text { Treaty }}_{i j}$, for which there a strong mechanical multicollinearity between it and Treaty $y_{i j T}$ due to the fact that, over our sample, BTTs are introduced and never eliminated. Regardless, the estimate in Column (5) is significant at the five percent level and an F-test reveals (i.e., the joint test of Treaty ${ }_{i j T}$ and $\overline{\text { Treaty }}_{i j}$ ) that the positive effect of BTTs is significant at the one-percent level. Moreover, Column (6) excludes $\overline{\text { Treaty }}_{i j}$ and shows that the coefficient remains the same, suggesting that the timing of treaty signings for country-pairs is indeed exogenous. Thus, Column (6) is our preferred specification and we exclude $\overline{\text { Treaty }}_{i j}$ in all subsequent columns and tables that include correlated random effects unless otherwise noted.

The effect of trade in Column (6) of Table 3 is 0.139 and is significant at the five percent level. The coefficient implies that increasing trade by one standard deviation increases the correlation between the two countries' GDP series by 0.351 of a standard deviation in observed business cycle comovement. Put differently, signing a BTT has an effect on comovement corresponding quantitatively to roughly a one-and-a-half standard deviation increase in trade, highlighting the substantial economic significance of fiscal policy coordination between countries.

The coefficient on corporate tax rate differences is 0.004 and significant at the five percent level in Column (6). This implies that a one standard deviation increase in corporate tax rate differences between two countries increases comovement by 0.149 of a standard deviation in observed business cycle comovement. This result emphasizes the fact that while coordinating tax bases - as measured by signing BTTs - substantially increases comovement, synchronizing tax rates across countries does the opposite. This is not surprising as both increasing tax base coordination and decreasing tax rate coordination likely induce more investment abroad, increasing the exposure of the domestic economy to foreign shocks.

Consistent with the evidence in Baxter \& Kouparitsas (2005), currency union membership also has an insignificant impact on comovement in Column (6), with a point estimate of -0.055 Entering into a currency union does not increase cyclical comovement, which is particularly unfortunate and echoes well-known challenges that have been faced by the European Union: if entering into a monetary union does not cause all countries in the union to face the same cyclical shocks, then 
monetary policy in such a union may not be a very valuable policy tool to smooth volatility across nations. These results contrast sharply with the positive and significant impact of fiscal policy coordination on comovement.

Columns (7) and (8) report the results from additional specifications. In Column (7) we exclude the 2000s decade to address potential concerns that the outlying observations from the latest recession impact our estimates. Even when eliminating these observations, we continue to find a positive and significant effect of BTTs that corresponds closely in magnitude to the estimates from the entire sample period. In Column (8) of Table 3 we introduce additional intentional agreements into the GEE strategy that might also influence comovement relationships: bilateral investment treaties (BITs) and free trade agreements (FTAs). ${ }^{27}$ One might be concerned that the estimated effect of Treaty is actually capturing the propensity to sign agreements that integrate national economies, but it is the changes in economic activity associated with the other trade and investment accords that actually influence comovement. However the introduction of BITs and FTAs in Column (8) has almost no impact on the quantitative effect of Treaty, and the result remains significant at the one percent level. ${ }^{28}$ BITs have a strong negative impact and FTAs have a strong positive impact on business cycle comovement, but importantly these effects appear to be independent of the role of fiscal policy coordination.

\subsection{Trend Comovement}

For many countries, shocks to output trends constitute a sizable fraction of the total variation in GDP over time. Given their permanent nature, changes in the comovement of shocks to GDP trends may also have more important consequences for nations over the long-run. Plus, the transmission of output shocks, and hence the role of fiscal policy coordination, may differ between trend shocks and cyclical shocks. For all these reasons, in Table 4 we examine comovement in shocks to GDP trends, as an alternative to business cycle comovement. We continue to implement the GEE empirical strategy and report standard errors clustered at the country-pair level.

Columns (1) - (2) of Table 4 examine the effect of signing a BTT on the comovement of trend

\footnotetext{
${ }^{27}$ The intended purpose of bilateral investment treaties is to secure the property rights of foreign investments with respect to, say, concerns about nationalization of assets or limits on transfer of investment related funds. These agreements are quite distinct from fiscal policy instruments such as BTTs.

${ }^{28}$ The time averages of treaty status for BITs and FTAs $\left(\overline{B I T}_{i j}\right.$ and $\left.\overline{F T A}_{i j}\right)$ are excluded from this regression for the same reason as $\overline{\text { Treaty }}$ is excluded.
} 
shocks without unobserved country-pair effects, while Columns (3)-(6) implement our preferred strategy and estimate the model with correlated random effects. The estimated impact of BTTs are remarkably stable across these columns.

Our preferred estimates are in Column (4); the specification corresponds to our preferred specification estimating the response of cyclical comovement in Table 3. The estimate of Treaty is 0.026 and is significant at the five percent level, which implies that signing a new BTT will increase the correlation of GDP trends between the two countries by 0.215 of a standard deviation. Although the estimated effect of BTTs on the comovement of trend shocks appears smaller than the $1 / 2$ standard deviation increase in cyclical comovement, this does not imply that the economic impact is smaller. Over the long-run, shocks to a nations' output trends can be quantitively more important in explaining the overall variation in their GDP series. Hence, despite the relatively smaller impact of BTTs on comovement in trend shocks within a particular decade, the impact of fiscal policy coordination is still economically substantial. ${ }^{29}$

The decade fixed effects included in Column (4) of Table 4 are consistent with the pattern of trend comovement across time that was depicted in Figure 1. Trade linkages have a marginally significant and negative effect on trend comovement, which is consistent with the results in Blonigen, Piger \& Sly (2012). The coefficient on GDP per capita differences is - 0.183 and significant at the one percent level. The coefficient on the corporate tax rate difference is negative and significant at the five percent level, which contrasts with its positive estimated impact on business cycle comovement. Permanent shocks are likely to better incentivize firms to relocate production facilities and take advantage of tax rate differences than cyclical shocks. This sort of substitution of activity across countries implies that tax rate differences are less likely to lead to transmission of permanent shocks as compared to cyclical shocks. One surprising result is the positive and significant impact of currency union membership on trend comovement. The coefficient on currency union in Column (4) is 0.057 and is significant at the five percent level; put differently, introducing a currency union appears to increase trend comovement among member nations by 0.471 of a standard deviation.

Column (6) adds FTAs and BITs. The addition of these variables has a negligible effect on the

\footnotetext{
${ }^{29}$ Similarly, Blonigen, Piger \& Sly (2012) simulate changes in ten-year output growth correlations corresponding to the estimated effects of trade linkages and show that indeed the impact on trend comovement is quantitatively more important than its effect on cyclical comovement, despite the fact that trade linkages have a smaller estimated impact on trend comovement.
} 
other estimated coefficients. We find that FTAs promote comovement in trend shocks, consistent with its positive impact of trade agreements on cyclical comovement. Likewise, members of the EU customs union exhibit stronger trend comovement on average. BITs have a near zero effect on trend comovement.

\subsection{Heterogeneous Effects of Fiscal Policy}

Much of the prior literature on comovement has emphasized significant heterogeneity in both the propensity for different countries to comove, and the impacts of country characteristics in promoting the transmission of shocks across borders. For example, member nations of the G7 are known to exhibit stronger degrees of comovement relative to non-members (Kose et al. (2003)). ${ }^{30}$ Finally, there is prior evidence that the role of trade and financial linkages in promoting comovement across countries differs between G7 and non-G7 members (Kose, Otrok \& Prasad (2012)).

Besides the differences between G7 and non-G7 nations, there may also be important differences in the effects of BTTs across countries with different levels of initial comovement. Fiscal policy coordination may symmetrically raise the correlation between shocks to nations' GDP series. Alternatively, it may be the case that nations with negatively correlated business cycles have even more diametrically opposed cycles after treaties enter into force, while those with positive comovement have even more synchronized business cycle after signing a new BTT.

Recognizing these differences, in this section we examine the heterogeneous effects of fiscal policy coordination by (i) examining sub-samples of country-pairs with and without G7 nations separately, and (ii) estimating kernel density estimates of cyclical and trend comovement over the entire distribution of observed comovement according to treaty status and time.

\subsubsection{Results by G7 Membership}

In Table 5, we estimate the effects of BTTs separately for country-pairs in which neither country is a member of the G7, and country-pairs for which one country is a member of the G7. Specification (1) includes only period-specific effects, while specification (2) introduces additional covariates and specification (3) is our preferred approach that includes all covariates, time-period effects, and

\footnotetext{
${ }^{30}$ Many influential studies have focused their analysis exclusively on G7 nations: see for example Doyle \& Faust (2005) and Kose, Otrok \& Whiteman (2008)
} 
country-pair correlated random effects. ${ }^{31}$

Row 1 of Table 5 reports the effect of BTTs on business cycle comovement from each specification separately for G7 and non-G7 membership. A striking pattern emerges: for nations outside the G7 there appears to be little robust effect of fiscal policy coordination, while country-pairs that include G7 nations realize significant increases in cyclical comovement once a new BTT enters into force. ${ }^{32}$ The greater efficacy of BTTs on cyclical comovement amongst the G7 nations mirrors the results found in previous studies regarding trade and financial integration. Outside large industrial nations such fiscal, financial or trade linkages appear to play little role in the transmission of business cycles. However, Row 2 of Table 5 demonstrates that to consider only cyclical shocks would ignore another important moment of GDP comovement: namely, the propensity to share trend shocks.

While fiscal policy coordination seems to have no impact on business cycle comovement outside the G7, there appears to be a positive and significant impact on the comovement of trend shocks. Also in contrast to the results for cyclical comovement, the estimated effects of BTTs on trend comovement are an order of magnitude smaller for G7 pairs than for non-G7 nations, and indistinguishable from zero. These results highlight the importance of considering both cyclical comovement and comovement in shocks to output trends. While fiscal policy seems to impact nations differently, it would be an error to conclude that BTTs have no impact on the comovement of any subset of nations' output series. Rather, the effects of fiscal policy coordination are realized at different moments of the GDP series for different sets of countries.

\subsubsection{Results from Non-Parametric Estimates}

The last section considered heterogeneity in effects according to G7 membership, but there may be other important differences across the distribution of observed comovement levels. There may even be important non-monotonicities in the effects of treaties across initial comovement levels. As an alternative approach, we estimate the kernel density of observed comovement separately across observations in which there is a treaty in force between countries for each decade in our sample,

\footnotetext{
${ }^{31}$ Each G7 nation had a BTT in force with other members prior to the sample period, which precludes estimating the effects of BTTs within the G7 exclusively when correlated random effects are included. Note that when covariates are included, the specification is identical to those reported previously Table 3 Column (8); for the sake of brevity, we suppress the estimates of all control variables and focus on the role of BTTs.

${ }^{32}$ Splitting the sample according to G7 membership does reduce the power available to estimate the impact of BTTs. Still, in each specification the point estimate on BTT is an order of magnitude smaller for pairs outside the G7, suggesting that the insignificant impact is not simply due less efficient estimation.
} 
and observations for which there is not. ${ }^{33}$ We only include country-pairs who change treaty status during our window of analysis.

The non-parametric estimates of the effect of signing a BTT on cyclical comovement are in Figure 2. This figure suggests that if cyclical comovement was negative before the BTT was signed, the treaty decreases the degree of negative comovement, and if comovement was positive before the treaty was signed, it increases the degree of positive comovement. The center mass of the distribution of comovement in periods prior to the BTT is near zero, but increases after the treaty enters into force. Put another way, signing a BTT appears to increase cyclical comovement for any degree of prior comovement. This fact confirms that the results in the parametric models are not driven by outliers in the sample. More importantly, the broad ranging effects of fiscal policy coordination across country-pairs and time speak directly to the efficacy of such policies in linking nations' business cycles. The Kolmogorov-Smirnov test statistic for differences between the distributions is significant at the five percent level, showing that these densities are significantly different by treaty status and time period.

The non-parametric estimates of the effect of signing a BTT on trend comovement are displayed in Figure 3. This figure suggests that signing a BTT increases comovement for all previous levels of comovement, including zero. The entire distribution of observed trend comovement shifts to the right, as with business cycle comovement. The Kolmogorov-Smirnov test statistic is significant at the one percent level, showing that this movement in the density when a BTT is introduced is statistically significant. The shifts in the kernel density estimates across treaty status in Figures 2 and 3 are consistent with the results of the parametric estimation reported above.

Given the nature of changing cyclical and trend comovement across time, one could worry that the conclusions drawn from Figures 2 and 3 are simply due to the changing comovement across time that are disproportionately included in the pre or post period. This concern is particularly relevant for trend comovement, which increased sharply in the 2000s relative to the rest of the sample. To address such concerns we examined Figure 2 separately by decade and found the same general pattern across each decade. ${ }^{34}$ Observing that trend comovement was almost constant in

\footnotetext{
${ }^{33}$ Note that as in the parametric estimation above, each country-pair has three observations included in the non-parametric estimation. Each of these observations within pairs will belong to different kernel density estimates according treaty status across time.

${ }^{34}$ The small hump on the right side of the post-treaty density of cyclical comovement disappears, but the general shift to the right remains, and the kernel densities are still significantly different (at the five percent level) across
} 


\section{Figure 2: Kernal Density Estimates of Cyclical Comovement Before and After Treaty in Force}

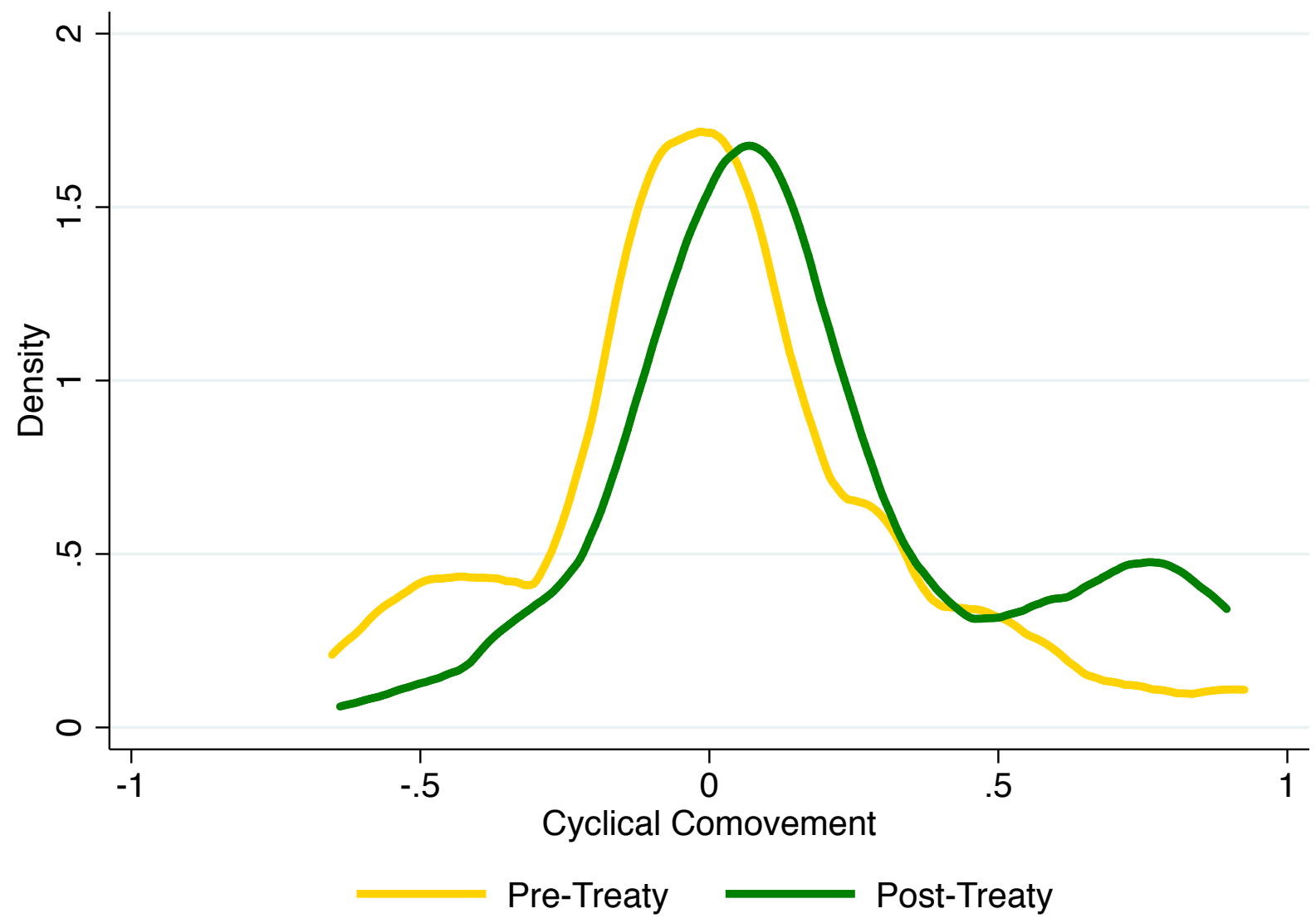

This figure plots the kernel density estimate of decade cyclical comovement before (yellow line) and after (green line) a treaty is put into force. The bandwidth is 0.092. An Epanechnikov kernel is used. The p-value of the Kolmogorov-Smirnov statistic comparing these two densities is 0.001 . 


\section{Figure 3: Kernal Density Estimates of Trend Comovement Before and After Treaty in Force}

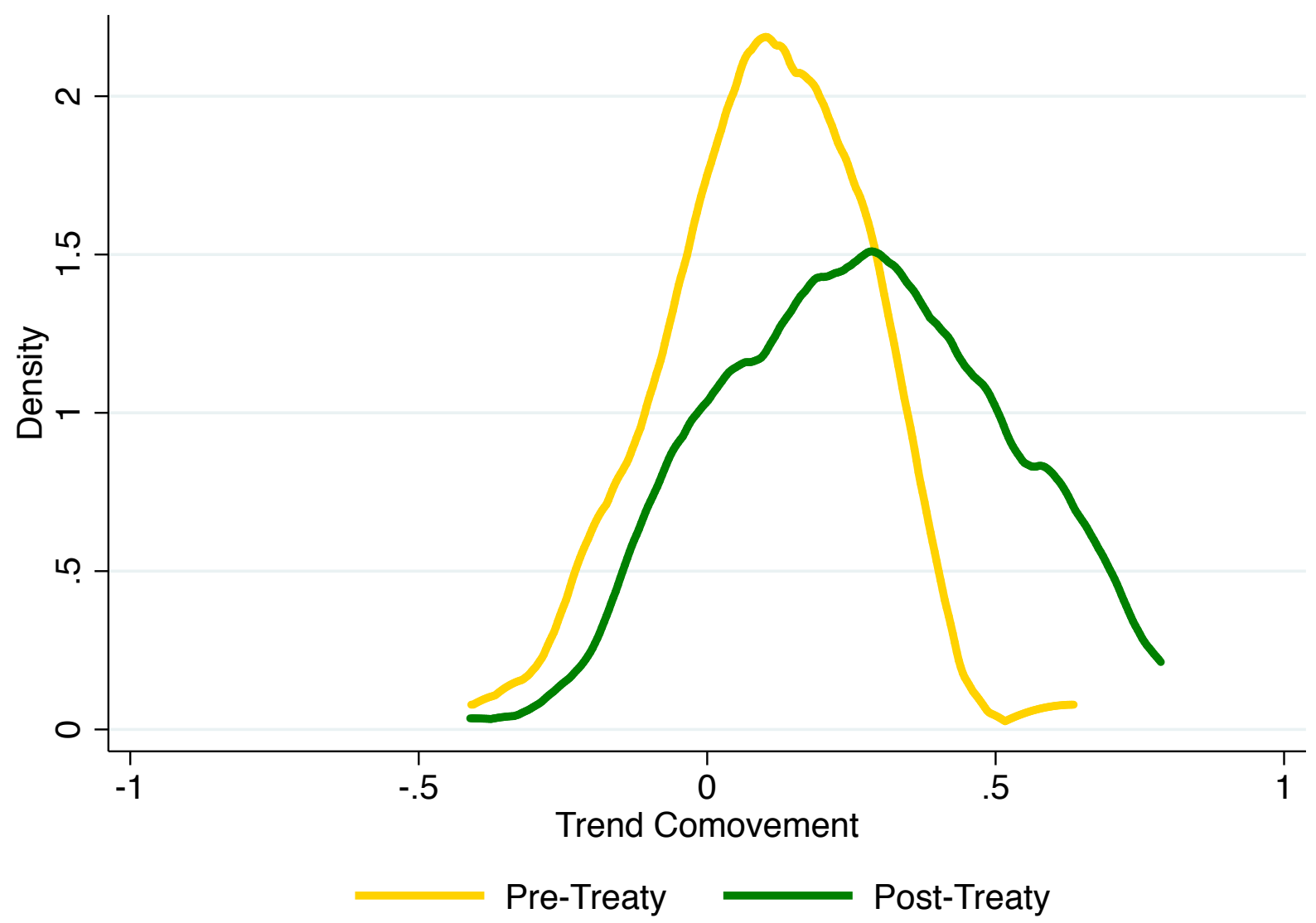

This figure plots the kernel density estimate of decade trend comovement before (yellow line) and after (green line) a treaty is put into force. The bandwidth is 0.065. An Epanechnikov kernel is used. The p-value of the Kolmogorov-Smirnov statistic comparing these two densities is 0.000 . 
the 1980's and 1990's, but increased drastically in the 2000's due to the global recession in 2008, we exclude the 2000's and recalculate the trend comovement figure. This decreases the rightward shift in the post-period and the densities are marginally insignificantly different from one another.

\subsection{Alternative Definitions of Comovement}

Up to this point we have focused our analysis on comovement as measured by the correlation in cyclical or trend shocks between countries over a decade period. Also, in the analysis above we have used measures of GDP trends and cycles obtained from the preferred UC model; however many studies of comovement have used a HP filter to extract the components of nations' output series. In this section, we consider alternative definitions of the dependent variable to further demonstrate the robustness of our results. Specifically, we consider (i) various time-spans besides a decade over which we define comovement periods for each country-pair, and (ii) the effect of BTTs with comovement measured as the correlation in business cycles estimated using an HP filter.

\subsubsection{Comovement Periods}

Table 6 presents estimates from our GEE empirical strategy when the correlation between cyclical and trend shocks are taken from 8-year and 12-year windows. We consider three specifications. The first specification includes only period-specific effects corresponding to the time period used to estimate the comovement window, the second introduces additional covariates and the third is our preferred approach that includes all covariates, time-period effects and is estimated with countrypair correlated random effects. ${ }^{35}$ To aid in comparison we also repeat the estimates obtained from a 10-year window in Columns (1)-(3). We continue to report standard errors clustered at the country-pair level. It is important to note that the goal in Table 6 is to examine if BTTs have a robust and positive effect on comovement when considering different time spans; however the estimated effects of BTTs are not comparable across different windows as the change in the length of the period in the dependent variable implies different economic consequences of fiscal policy.

In Row (1) of Table 6, consider business cycle comovement across different time windows. Col-

\footnotetext{
treaty status.

${ }^{35}$ Note that when covariates are included the reported estimate is from a specification identical to those reported previously Table 3 Column (8); for the sake of brevity, we suppress the estimates of all control variables and focus on the BTT estimates.
} 
umn (4) includes only Treaty and period-specific effects in the regression using 8-year comovement in business cycles as the dependent variable. In Column (5) we introduce additional covariates, while Column (6) is our preferred specification for the 8-year window, which is estimated using correlated random effects to account for pair-specific unobservables. Treaty continues to have a positive, statistically significant, impact on cyclical comovement in each of these columns. In Columns (7)-(9) we report estimates obtained when defining the business cycle comovement period according to a 12-year window. In all specifications for the 12-year window, we find that Treaty has a positive impact on comovement that is significant at the one percent level.

Row (2) of Table 6 reports the estimated effects of BTTs on trend comovement for different comovement periods. In all specifications, and for each variation in comovement period, the impact of fiscal policy coordination is positive and significant. Except for the estimate in Column (7), which includes no covariates and no correlated random effects, all specifications find that the effect of BTTs on trend comovement is significant at the one percent level. The stability of our results

in Table 6 for both trends and cycles across various definitions of comovement periods mitigates concerns about selection and measurement issues, and supports our conclusions that fiscal policy coordination promotes business cycle and trend comovement.

\subsubsection{Comovement Estimates from HP filter}

Many previous studies have used band-pass filters, such as the HP filter - the popular technique developed in Hodrick \& Prescott (1997) - to estimate the cyclical component of nations' GDP series and to construct measures of comovement. In the analysis above, we have conducted our cyclical comovement analysis using measures of comovement that are based on the cyclical component obtained from the UC model. The summary statistics in Table 1 demonstrates that there are substantial differences between measured comovement calculated from the UC model and HP filter. The average level of comovement over the sample obtained from the UC model is 0.248 with a standard deviation of 0.416 , while the average level of comovement calculated using the HP filter is 0.360 with a standard deviation of 0.370 . While the mean level of comovement is much higher for the HP filter, the observed variation is much smaller than for the UC model. Given the observed differences between these measures of our dependent variable, it is prudent to examine the robustness of the effects of fiscal policy across definitions of comovement. 
Table 5 reports the results from both the linear and GEE specifications where the dependent variable is the decade-long correlation in cyclical shocks estimated using the HP filter. In Columns (1)-(3) we sequentially introduce covariates and country-pair fixed effects in the linear model Columns (4)-(7) report estimates from the GEE model. We continue to find that BTTs exert a positive and significant effect on comovement across all columns; however, accounting for the boundedness of comovement using the GEE model matters substantially more for the quantitative estimates than it did when comovement was obtained from the UC model. This is likely due to the fact that there are substantially more observations near the upper bound when comovement is measured using the HP filter. Comparing our preferred linear model specification (Column (3)) to the comparable GEE model estimates (Column (6)), we see that the linear model produces an estimate on Treaty that is biased upwards by about half a standard deviation, the effects of trade and GDP per capita differences are biased downward by approximately half a standard deviation, and the estimated effect of a currency union is biased about three standard deviations downward. ${ }^{36}$

The effect of BTTs on comovement not only remains statistically significant when the HP filter is used to calculate comovement, but the quantitative magnitudes of the estimates from our preferred GEE specification remain approximately the same as when comovement was obtained from the UC model. In both cases, the effect of a new BTT is roughly one-and-a-half times larger than the effect of a one standard deviation increase in trade linkages. ${ }^{37}$ The robustness and quantitative similarity of the effects of BTTs across these various measure of comovement further support the conclusion that BTTs do indeed raise comovement between nations

\section{Conclusion}

Many countries exhibit large correlations between shocks to their GDP series over time. We have carefully documented in this paper that fiscal policy coordination increases the comovement of business cycle shocks and shocks to output trends. This fact has several broader implications. Beginning with Mundell (1961), a large literature has argued that similarity in shocks to nations'

\footnotetext{
${ }^{36}$ Recall that to estimate the GEE model observations of comovement were rescaled - see equation (2). To compare the impacts direction one must compare the relative effects of standard deviations in variables.

${ }^{37}$ We note that it one cannot compare the estimated effects across specifications directly given the differences in the way the dependent variable is measured. However, we can compare the relative effects of say, Trade and Treaty, within each specification.
} 
GDP series is an important criterion for optimal currency areas. Thus, our results indicate that fiscal policy coordination, by raising the comovement in both the cycle and trend components of aggregate output, could make countries more suitable for currency union membership. This fact has obvious relevance to the European Economic and Monetary Union that is still debating fiscal policies with other member nations.

The potential of fiscal policy coordination to facilitate the transmission of output shocks across borders means that a larger portion of the total fluctuations in a nations' GDP series may actually originate abroad. This can increase the strain on domestic policies - fiscal, monetary and commercial - to smooth volatility at home, since foreign shocks are outside their scope of influence. If greater international fiscal policy coordination can potentially weaken the ability of domestic policy to smooth volatility, there may be important deadweight loss implications. In this regard, Seegert (2012) argues that the the negative welfare consequences of aggregate volatility are substantial.

Our results also highlighted that the effects of fiscal policy coordination are symmetric across nations whose GDP series tend to positively or negatively comove. Regardless of their prior level of comovement, we find evidence that BTTs raise the overall correlation between aggregate shocks. This fact speaks to the potential efficacy of fiscal policy across a broad set of countries. 


\section{References}

Acemoglu, D. (2009). Introduction to Modern Economic Growth. Princeton, NJ: Princeton University Press.

Aguiar, M. \& Gopinath, G. (2007). Emerging market business cycles: The cycle is the trend. Journal of Political Economy, 115(1).

Backus, D. K., Kehoe, P. J., \& Kydland, F. E. (1992). International real business cycles. Journal of Political Economy, 100(4), 745-775.

Barro, R. J. (2012). Convergence and modernization revisited. mimeo Harvard University.

Baxter, M. \& King, R. G. (1999). Measuring business cycles: Approximate band-pass filters for economic time series. Review of Economics and Statistics, 81(4), 575-593.

Baxter, M. \& Kouparitsas, M. A. (2005). Determinants of business cycle comovement: A robust analysis. Journal of Monetary Economics, 52(1), 113-57.

Beveridge, S. \& Nelson, C. R. (1981). A new approach to decomposition of economic time series into permanent and transitory components with particular attention to measurement of the 'business cycle'. Journal of Monetary Economics, 7(2), 151-174.

Blonigen, B. A., Oldenski, L., \& Sly, N. (2012). Separating the opposing effects of bilateral tax treaties. NBER working paper 17480.

Blonigen, B. A., Piger, J., \& Sly, N. (2012). Comovement in GDP trends and cycles among trading partners. University of Oregon.

Boudoukh, J., Richardson, M., \& Whitelaw, R. F. (1994). Industry returns and the Fisher effect. Journal of Finance, 49(5), 1595-1615.

Burstein, A., Kurz, C., \& Tesar, L. L. (2008). Trade, production sharing and the international transmission of business cycles. Journal of Monetary Economics, 55, 775-795.

Calderon, C., Chong, A., \& Stein, E. (2007). Trade intensity and business cycle synchronization: Are developing countries different. Journal of International Economics, 71 (1), 2-21.

Chamberlain, G. (1980). Analysis of variance with qualitative data. Review of Economic Studies, 47, 225-38.

Claessens, S. \& Forbesi, K. J. (2001). International Financial Contagion. Springer Science+Business Media New York.

Clark, P. K. (1987). The cyclical component of economic activity. Quarterly Journal of Economics, 102(4), 797-814.

Clark, T. E. \& van Wincoop, E. (2001). Borders and business cycles. Journal of International Economics, 55, 59-85.

Cogley, T. (1990). International evidence on the size of the random walk in output. Journal of Political Economy, 98, 501-18. 
Cogley, T. (2001). Alternative definitions of the business cycle and their implications for business cycle models: A reply to Torben Mark Pedersen. Journal of Economic Dynamics and Control, $25(8), 1103-1107$.

Cogley, T. \& Nason, J. M. (1995). Effects of the hodrick-prescott filter on trend and difference stationary time series: Implications for business cycle research. Journal of Economic Dynamics and Control, 19(1-2), 253-278.

Corsetti, G., Kuester, K., \& Muller, G. J. (2011). Floats, pegs and the transmission f fiscal policy. mimeo University of Cambridge.

Corsetti, G., Müller, G. J., \& Sibert, A. (2008). Twin deficits: squaring theory, evidence and common sense. Economic Policy, 21(48), 597+599-638.

Davies, R. B., Norback, P.-J., \& Tekin-Koru, A. (2009). The effect of tax treaties on multinational firms: new evidence from micro-data. The World Economy, 32(1), 77-110.

Doyle, B. M. \& Faust, J. (2005). Breaks in the variability and comovement of G-7 economic growth. Review of Economics and Statistics, 87(4), 721-740.

Easson, A. (2000). Do we still need tax treaties? Bulletin for International Fiscal Documentation, $54,619-625$.

Egger, P., Larch, M., Pfaffermayr, M., \& Winner, H. (2006). The impact of endogenous tax treaties on foreign direct investment: Theory and empirical evidence. Canadian Journal of Economics, $39(3), 901-931$.

Feyrer, J. \& Shambaugh, J. (2012). Global savings and global investment: the transmission fiscal shocks. American Economic Journal: Economic Policy, 4(2), 95-114.

Forbes, K. J. \& Gigobon, R. (2002). No contagion, only interdependence: measuring stockmarket comovments. The Journal of Finance, 57(5), 2223-61.

Frankel, J. A. \& Rose, A. K. (1998). The endogeneity of optimum currency area criteria. The Economic Journal, 108(449), 1009-1025.

Frenkel, J. A. \& Razin, A. (1986). Fiscal policies in the world economy. Journal of Political Economy, 94(3), 564-94.

Guerrieri, L., Iacoviello, M., \& Minetti, R. (2012). Banks, sovereign debt, and the international transmission of business cycles. In F. Giavazzi \& K. D. West (Eds.), International Seminar on Macroeconomics (ISOM). NBER.

Harvey, A. C. (1985). Trends and cycles in macroeconomic time series. Journal of Business and Economic Statistics, 3(3), 216-227.

Harvey, A. C. \& Jaeger, A. (1993). Stylized facts and the business cycle. Journal of Applied Econometrics, 8(3), 231-247.

Hodrick, R. J. \& Prescott, E. C. (1997). Postwar U.S. business cycles: An empirical investigation. Journal of Money, Credit and Banking, 29(1), 1-16.

Imbs, J. (2004). Trade, finance specialization and synchronization. Review of Economics and Statistics, 86(3), 723-734. 
Imbs, J. \& Wacziarg, R. (2003). Stages of diversification. American Economic Review, 93(1), $63-86$.

Karolyi, G. A. \& Stulz, R. M. (1996). Why do markets move together? An investigation of U.S.-Japan stock return comovements. Journal of Finance, 51(3), 951-86.

Kawano, L. \& Slemrod, J. (2012). The effect of tax rates and tax bases on corporate tax revenues: Estimates with new measures of the corporate tax base. NBER working paper 18440.

Kim, C.-J. \& Nelson, C. R. (1998). Business cycle turning points, and new coincident index, and tests of a duration dependence based on a dynamic factor model with regime switching. The Review of Economics and Statistics, 80(2), 188-201.

Kleinert, J., Martin, J., \& Toubal, F. (2012). The few leading the many: Foreign affiliates and business cycle comovement. mimeo Paris School of Economics.

Kose, M. A., Otrok, C., \& Prasad, E. S. (2012). Global business cycles: Converging or decoupling. International Economic Review, 53(2), 511-538.

Kose, M. A., Otrok, C., \& Whiteman, C. (2008). Understanding the evolution of world business cycles. Journal of International Economics, 75(1), 110-130.

Kose, M. A., Prasad, E. S., \& Terrones, M. E. (2003). How does globalization affect the synchronization of business cycles? American Economic Review, 93(2), 57-62.

Levchenko, A. \& di Giovanni, J. (2010). Putting the parts together: Trade, vertical linkages and business cycle comovement. American Economic Journal: Macroeconomics, 2(2), 95-124.

Morley, J. C., Nelson, C. R., \& Zivot, E. (2003). Why are the Beveridge-Nelson and UnobservedComponents decompositions of GDP so different? Review of Economics and Statistics, 85(2), $235-243$.

Mundell, R. (1961). A theory of optimum currency areas. American Economic Review, 85(3), $615-23$.

Mundlak, Y. (1978). On the pooling of time series and cross section data. Econometrica, 46, 69-85.

Murray, C. J. (2003). Cyclical properties of Baxter-King filtered time series. Review of Economics and Statistics, 85(2), 472-476.

Papke, L. E. \& Wooldridge, J. M. (1996). Econometric methods for fractional response variables with an application to 401(k) plan participation rates. Journal of Applied Econometrics, 11, 619-632.

Papke, L. E. \& Wooldridge, J. M. (2008). Panel data methods for fractional response variables with an application to test pass rates. Journal of Econometrics, 145, 121-133.

Pedersen, T. M. (2001). The hodrick-prescott filter, the slutzky effect, and the distortionary effect of filters. Journal of Economic Dynamics and Control, 25 (8), 1081-1101.

Rodrik, D. (2011). Unconditional convergence. NBER working paper 17546.

Rose, A. K. \& Engel, C. (2002). Currency unions and international integration. Journal of Money, Credit and Banking, 34(4), 2002. 
Rotemberg, J. J. \& Woodford, M. (1996). Real-business-cycle models and the forecastable movements in output, hours, and consumption. American Economic Review, 86(1), 71-89.

Seegert, N. (2012). Optimal taxation with volatility: A theoretical and empirical decomposition. mimeo Univeristy of Michigan.

Watson, M. W. (1986). Univariate detrending methods with stochastic trends. Journal of Monetary Economics, 18(1), 49-75.

Wooldridge, J. M. (2010). Econometric Analysis of Cross Section and Panel Data (2nd Edition). Cambridge, MA: MIT Press. 
Table 2: Cyclical Comovement with Linear Response Model

\begin{tabular}{|c|c|c|c|c|c|c|}
\hline & (1) & $(2)$ & $(3)$ & $(4)$ & $(5)$ & $(6)$ \\
\hline Treaty & $\begin{array}{l}0.277^{* * *} \\
(0.051)\end{array}$ & $\begin{array}{l}0.163^{* * *} \\
(0.051)\end{array}$ & $\begin{array}{l}0.197^{* * *} \\
(0.054)\end{array}$ & $\begin{array}{c}0.163^{*} \\
(0.087)\end{array}$ & $\begin{array}{c}0.206^{* *} \\
(0.088)\end{array}$ & $\begin{array}{c}0.230^{* *} \\
(0.107)\end{array}$ \\
\hline Trade & & $\begin{array}{l}0.105^{* * *} \\
(0.034)\end{array}$ & $\begin{array}{l}0.110^{* * *} \\
(0.034)\end{array}$ & $\begin{array}{c}0.164 \\
(0.140)\end{array}$ & $\begin{array}{c}0.225^{* *} \\
(0.107)\end{array}$ & $\begin{array}{c}0.101 \\
(0.212)\end{array}$ \\
\hline GDP Per Capita Diffs & & $\begin{array}{c}-0.749^{* * *} \\
(0.188)\end{array}$ & $\begin{array}{c}-0.635^{* * *} \\
(0.201)\end{array}$ & $\begin{array}{c}-0.843^{* * *} \\
(0.259)\end{array}$ & $\begin{array}{c}-0.267 \\
(0.239)\end{array}$ & $\begin{array}{c}-2.390^{* * *} \\
(0.411)\end{array}$ \\
\hline Corporate Tax Rate Diffs & & $\begin{array}{c}0.003 \\
(0.002)\end{array}$ & $\begin{array}{c}0.002 \\
(0.003)\end{array}$ & $\begin{array}{l}0.012^{\text {*** }} \\
(0.004)\end{array}$ & $\begin{array}{l}0.008^{* *} \\
(0.004)\end{array}$ & $\begin{array}{l}0.014^{* * *} \\
(0.005)\end{array}$ \\
\hline Currency Union & & $\begin{array}{l}0.188^{* * *} \\
(0.065)\end{array}$ & $\begin{array}{c}0.129^{*} \\
(0.069)\end{array}$ & $\begin{array}{c}0.025 \\
(0.065)\end{array}$ & $\begin{array}{r}-0.115^{*} \\
(0.066)\end{array}$ & \\
\hline G7 & & $\begin{array}{l}0.117^{* * *} \\
(0.042)\end{array}$ & $\begin{array}{l}0.112^{* * *} \\
(0.042)\end{array}$ & & & \\
\hline 1990's FE & $\begin{array}{c}-0.219^{* * *} \\
(0.032)\end{array}$ & & $\begin{array}{c}-0.224^{* * *} \\
(0.033)\end{array}$ & & $\begin{array}{c}-0.204^{* * *} \\
(0.036)\end{array}$ & $\begin{array}{c}-0.233^{* * *} \\
(0.038)\end{array}$ \\
\hline 2000's FE & $\begin{array}{c}0.019 \\
(0.030)\end{array}$ & & $\begin{array}{c}-0.037 \\
(0.038)\end{array}$ & & $\begin{array}{c}0.045 \\
(0.042)\end{array}$ & \\
\hline Country-Pair FE & No & No & No & Yes & Yes & Yes \\
\hline Include 2000's & Yes & Yes & Yes & Yes & Yes & No \\
\hline Observations & 630 & 630 & 630 & 630 & 630 & 420 \\
\hline Country-Pairs & 210 & 210 & 210 & 210 & 210 & 210 \\
\hline
\end{tabular}

All standard errors are clustered by country-pair. ${ }^{* * *}$ indicates significance at the 1 percent level, ${ }^{* *}$ indicates significance at the 5 percent level, and ${ }^{*}$ indicates significance at the 10 percent level. 
Table 3: Cyclical Comovement with Fractional Response Model

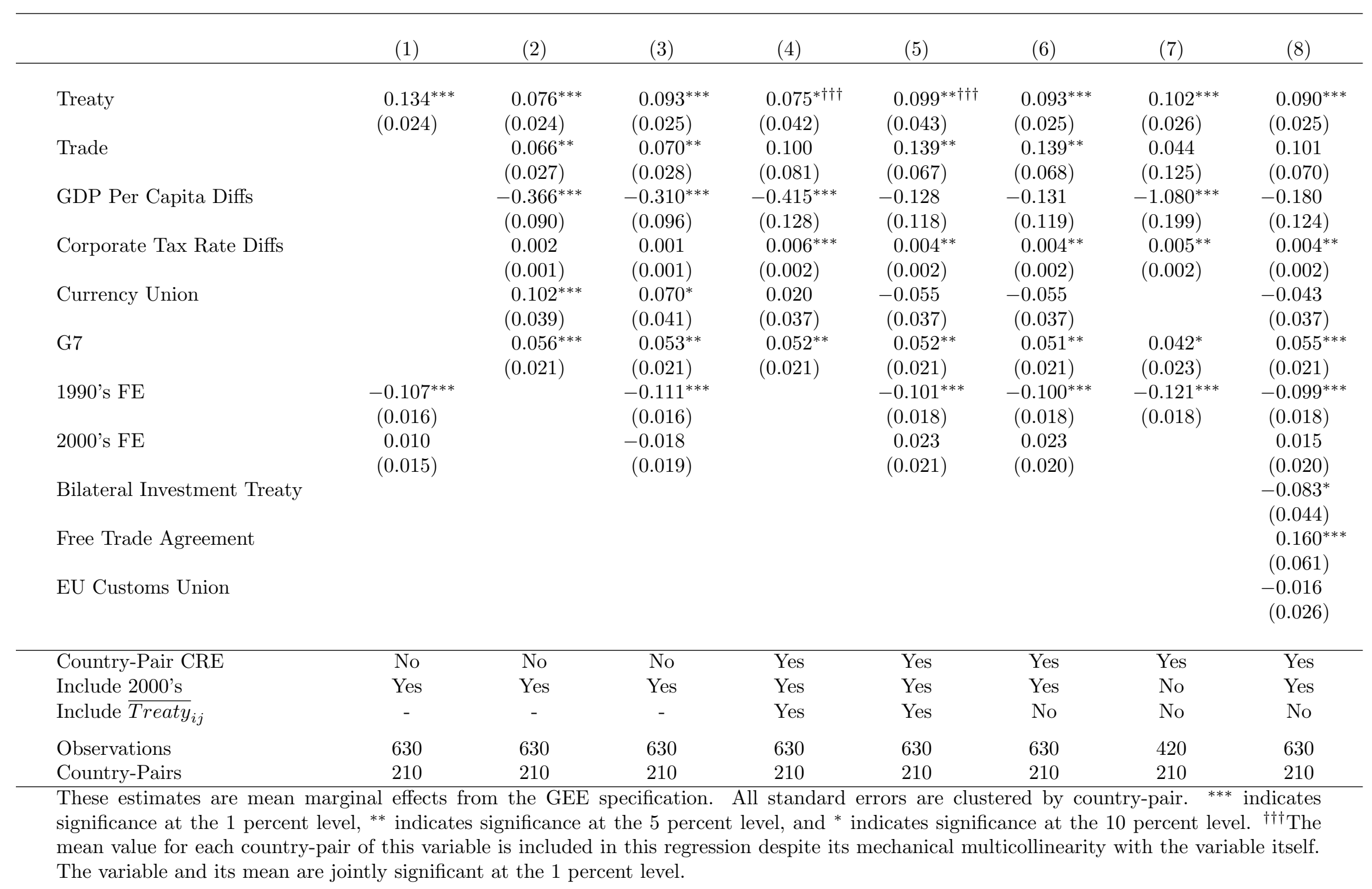


Table 4: Trend Comovement with Fractional Response Model

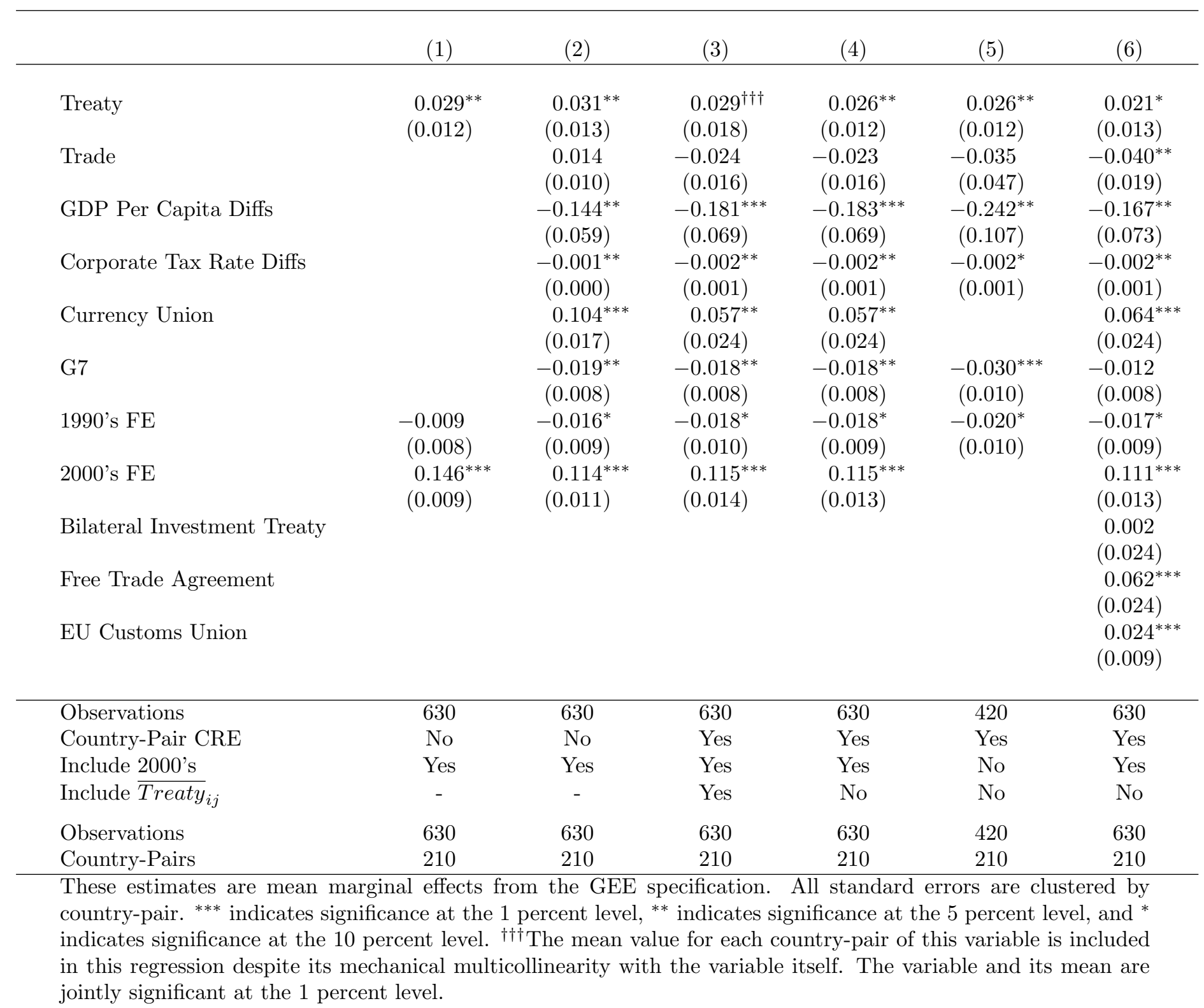


Table 5: Heterogeneous Responses to Treaty

\begin{tabular}{|c|c|c|c|c|c|c|}
\hline & \multicolumn{2}{|c|}{$(1)$} & \multicolumn{2}{|c|}{$(2)$} & \multicolumn{2}{|c|}{$(3)$} \\
\hline & Non-G7 & G7 & Non-G7 & G7 & Non-G7 & G7 \\
\hline \multirow[b]{2}{*}{ Treaty } & \multicolumn{6}{|c|}{ Cyclical Comovement } \\
\hline & $\begin{array}{c}0.055 \\
(0.036)\end{array}$ & $\begin{array}{l}0.190^{* * *} \\
(0.033)\end{array}$ & $\begin{array}{c}0.031 \\
(0.036)\end{array}$ & $\begin{array}{l}0.163^{* * *} \\
(0.034)\end{array}$ & $\begin{array}{c}0.049 \\
(0.033)\end{array}$ & $\begin{array}{l}0.153^{* * *} \\
(0.040)\end{array}$ \\
\hline \multirow[b]{2}{*}{ Treaty } & \multicolumn{6}{|c|}{ Trend Comovement } \\
\hline & $\begin{array}{l}0.049^{* * *} \\
(0.019)\end{array}$ & $\begin{array}{c}0.012 \\
(0.012)\end{array}$ & $\begin{array}{c}0.047^{* *} \\
(0.020)\end{array}$ & $\begin{array}{c}0.008 \\
(0.012)\end{array}$ & $\begin{array}{c}0.070^{* *} \\
(0.029)\end{array}$ & $\begin{array}{c}0.010 \\
(0.021)\end{array}$ \\
\hline Covariates & No & No & Yes & Yes & Yes & Yes \\
\hline Decade FE & Yes & Yes & Yes & Yes & Yes & Yes \\
\hline Country-Pair CRE & No & No & No & No & Yes & Yes \\
\hline Include 2000's & Yes & Yes & Yes & Yes & Yes & Yes \\
\hline Include $\overline{\text { Treaty }}_{i j}$ & Yes & Yes & Yes & Yes & Yes & Yes \\
\hline Observations & 273 & 357 & 273 & 357 & 273 & 357 \\
\hline Country-Pairs & 91 & 119 & 91 & 119 & 91 & 119 \\
\hline
\end{tabular}


Table 6: Varying Time Windows for Cyclical Comovement with Fractional Response Model

\begin{tabular}{|c|c|c|c|c|c|c|c|c|c|}
\hline & \multicolumn{3}{|c|}{ 10-Year Comovement } & \multicolumn{3}{|c|}{ 8-Year Comovement } & \multicolumn{3}{|c|}{ 12-Year Comovement } \\
\hline & $(1)$ & $(2)$ & $(3)$ & $(4)$ & $(5)$ & $(6)$ & $(7)$ & $(8)$ & $(9)$ \\
\hline \multirow[b]{2}{*}{ Treaty } & \multicolumn{9}{|c|}{ Cyclical Comovement } \\
\hline & $\begin{array}{l}0.134^{* * *} \\
(0.024)\end{array}$ & $\begin{array}{l}0.093^{* * *} \\
(0.025)\end{array}$ & $\begin{array}{l}0.093^{* * *} \\
(0.025)\end{array}$ & $\begin{array}{l}0.091^{* * *} \\
(0.022)\end{array}$ & $\begin{array}{c}0.059^{* *} \\
(0.024)\end{array}$ & $\begin{array}{c}0.044^{*} \\
(0.024)\end{array}$ & $\begin{array}{l}0.129^{* * *} \\
(0.025)\end{array}$ & $\begin{array}{l}0.087^{* * *} \\
(0.026)\end{array}$ & $\begin{array}{l}0.093^{* * *} \\
(0.024)\end{array}$ \\
\hline \multirow[b]{2}{*}{ Treaty } & \multicolumn{9}{|c|}{ Trend Comovement } \\
\hline & $\begin{array}{l}0.029^{* *} \\
(0.012)\end{array}$ & $\begin{array}{c}0.031^{* *} \\
(0.013)\end{array}$ & $\begin{array}{c}0.026^{* *} \\
(0.012)\end{array}$ & $\begin{array}{l}0.032^{* * *} \\
(0.010)\end{array}$ & $\begin{array}{l}0.039^{* * *} \\
(0.011)\end{array}$ & $\begin{array}{l}0.038^{* * *} \\
(0.011)\end{array}$ & $\begin{array}{c}0.026^{* *} \\
(0.012)\end{array}$ & $\begin{array}{l}0.034^{* * *} \\
(0.012)\end{array}$ & $\begin{array}{l}0.033^{* * *} \\
(0.012)\end{array}$ \\
\hline Covariates & No & Yes & Yes & No & Yes & Yes & No & Yes & Yes \\
\hline Decade FE & Yes & Yes & Yes & Yes & Yes & Yes & Yes & Yes & Yes \\
\hline Country-Pair CRE & No & No & Yes & No & No & Yes & No & No & Yes \\
\hline Include 2000's & Yes & Yes & Yes & Yes & Yes & Yes & Yes & Yes & Yes \\
\hline Include $\overline{\text { Treaty }}_{i j}$ & No & No & No & No & No & No & No & No & No \\
\hline Observations & 630 & 630 & 630 & 630 & 630 & 630 & 420 & 420 & 420 \\
\hline Country-Pairs & 210 & 210 & 210 & 210 & 210 & 210 & 210 & 210 & 210 \\
\hline
\end{tabular}

These estimates are mean marginal effects from the GEE specification. All standard errors are clustered by country-pair. ${ }^{* * *}$ indicates significance at the 1 percent level, ${ }^{* *}$ indicates significance at the 5 percent level, and ${ }^{*}$ indicates significance at the 10 percent level. Period 2 is $1990-1999$ for 10-year comovement, 1988-1995 for 8-year comovement, and 1992-2003 for 12-year comovement. Period 3 is 2000-2009 for 10-year comovement, 1997-2004 for 8-year comovement, and there is no 3rd period for 12-year comovement. 
Table 7: Cyclical Comovement with HP Filter

\begin{tabular}{|c|c|c|c|c|c|c|c|}
\hline & $(1)$ & $(2)$ & $(3)$ & $(4)$ & $(5)$ & (6) & $(7)$ \\
\hline & \multicolumn{3}{|c|}{ Linear Model } & \multicolumn{4}{|c|}{ Fractional Response Model } \\
\hline Treaty & $\begin{array}{l}0.240^{* * *} \\
(0.042)\end{array}$ & $\begin{array}{l}0.210^{* * *} \\
(0.041)\end{array}$ & $\begin{array}{l}0.171^{* *} \\
(0.067)\end{array}$ & $\begin{array}{l}0.108^{* * *} \\
(0.018)\end{array}$ & $\begin{array}{l}0.092^{* * *} \\
(0.018)\end{array}$ & $\begin{array}{l}0.068^{* * \dagger \dagger \dagger} \\
(0.033)\end{array}$ & $\begin{array}{l}0.081^{* * *} \\
(0.018)\end{array}$ \\
\hline Trade & & $\begin{array}{c}0.035 \\
(0.029)\end{array}$ & $\begin{array}{c}0.123 \\
(0.076)\end{array}$ & & $\begin{array}{c}0.021 \\
(0.018)\end{array}$ & $\begin{array}{c}0.081^{*} \\
(0.042)\end{array}$ & $\begin{array}{c}0.081^{*} \\
(0.043)\end{array}$ \\
\hline GDP Per Capita Diffs & & $\begin{array}{c}-0.558^{* * *} \\
(0.195)\end{array}$ & $\begin{array}{r}-0.353^{*} \\
(0.205)\end{array}$ & & $\begin{array}{c}-0.240^{* * *} \\
(0.084)\end{array}$ & $\begin{array}{c}-0.138 \\
(0.099)\end{array}$ & $\begin{array}{c}-0.131 \\
(0.099)\end{array}$ \\
\hline Corporate Tax Rate Diffs & & $\begin{array}{c}-0.000 \\
(0.002)\end{array}$ & $\begin{array}{c}-0.010^{* * *} \\
(0.003)\end{array}$ & & $\begin{array}{c}-0.000 \\
(0.001)\end{array}$ & $\begin{array}{c}-0.005^{* * *} \\
(0.002)\end{array}$ & $\begin{array}{c}-0.005^{* * *} \\
(0.002)\end{array}$ \\
\hline Currency Union & & $\begin{array}{l}0.169^{* * *} \\
(0.024)\end{array}$ & $\begin{array}{c}0.006 \\
(0.045)\end{array}$ & & $\begin{array}{l}0.153^{* * *} \\
(0.020)\end{array}$ & $\begin{array}{l}0.078^{* * *} \\
(0.027)\end{array}$ & $\begin{array}{c}0.078^{* * *} \\
(0.027)\end{array}$ \\
\hline G7 & & $\begin{array}{c}0.036 \\
(0.028)\end{array}$ & & & $\begin{array}{c}0.019 \\
(0.014)\end{array}$ & $\begin{array}{c}0.019 \\
(0.014)\end{array}$ & $\begin{array}{c}0.020 \\
(0.014)\end{array}$ \\
\hline 1990's FE & $\begin{array}{c}-0.050^{* *} \\
(0.025)\end{array}$ & $\begin{array}{c}-0.062^{* *} \\
(0.025)\end{array}$ & $\begin{array}{c}-0.085^{* * *} \\
(0.026)\end{array}$ & $\begin{array}{c}-0.022^{* *} \\
(0.011)\end{array}$ & $\begin{array}{c}-0.027^{* *} \\
(0.011)\end{array}$ & $\begin{array}{c}-0.039^{* * *} \\
(0.012)\end{array}$ & $\begin{array}{c}-0.040^{* * *} \\
(0.011)\end{array}$ \\
\hline 2000's FE & $\begin{array}{l}0.420^{* * *} \\
(0.028)\end{array}$ & $\begin{array}{l}0.351^{* * *} \\
(0.032)\end{array}$ & $\begin{array}{l}0.348^{* * *} \\
(0.037)\end{array}$ & $\begin{array}{l}0.223^{* * *} \\
(0.015)\end{array}$ & $\begin{array}{l}0.187^{* * *} \\
(0.016)\end{array}$ & $\begin{array}{l}0.184^{* * *} \\
(0.019)\end{array}$ & $\begin{array}{l}0.182^{* * *} \\
(0.018)\end{array}$ \\
\hline Country-Pair FE/CRE & No & No & Yes & No & No & Yes & Yes \\
\hline Include $\overline{\text { Treaty }}_{i j}$ & - & - & - & No & No & Yes & No \\
\hline Include 2000's & Yes & Yes & Yes & Yes & Yes & Yes & Yes \\
\hline Observations & 630 & 630 & 630 & 630 & 630 & 630 & 630 \\
\hline Country-Pairs & 210 & 210 & 210 & 210 & 210 & 210 & 210 \\
\hline
\end{tabular}

All standard errors are clustered by country-pair. ${ }^{\dagger \dagger}$ The mean value for each country-pair of this variable is included in this regression despite its mechanical multicollinearity with the variable itself. The variable and its mean are jointly significant at the 1 percent level. 


\section{Table 8: New Treaties in Force by Year}

\begin{tabular}{|c|c|}
\hline Country-Pair & Year in Force \\
\hline Australia-Sweden & 1981 \\
\hline Australia-Denmark & 1981 \\
\hline Australia-Switzerland & 1981 \\
\hline Finland-Korea & 1981 \\
\hline France-Norway & 1981 \\
\hline France-Korea & 1981 \\
\hline Korea-Netherlands & 1981 \\
\hline Korea-Switzerland & 1981 \\
\hline Finland-Germany & 1982 \\
\hline Germany-Portugal & 1982 \\
\hline Korea-Sweden & 1982 \\
\hline Australia-Norway & 1983 \\
\hline Denmark-Italy & 1983 \\
\hline Finland-Italy & 1983 \\
\hline Italy-Portugal & 1983 \\
\hline Italy-Sweden & 1983 \\
\hline Japan-Sweden & 1983 \\
\hline Korea-New Zealand & 1983 \\
\hline New Zealand-Belgium & 1983 \\
\hline New Zealand-Norway & 1983 \\
\hline Australia-Korea & 1984 \\
\hline Canada-Sweden & 1984 \\
\hline Finland-New Zealand & 1984 \\
\hline Korea-Norway & 1984 \\
\hline Australia-Italy & 1985 \\
\hline Austria-Italy & 1985 \\
\hline Australia-Finland & 1986 \\
\hline Austria-Korea & 1987 \\
\hline Denmark-Norway & 1987 \\
\hline Denmark-Finland & 1987 \\
\hline Denmark-Sweden & 1987 \\
\hline Finland-Norway & 1987 \\
\hline Finland-Sweden & 1987 \\
\hline Italy-Norway & 1987 \\
\hline Norway-Sweden & 1987 \\
\hline Australia-Austria & 1988 \\
\hline Spain-United States & 1990 \\
\hline Australia-Spain & 1992 \\
\hline Canada-Mexico & 1992 \\
\hline France-Mexico & 1992 \\
\hline Italy-Korea & 1992 \\
\hline Mexico-Sweden & 1992 \\
\hline Germany-Mexico & 1993 \\
\hline Mexico-United States & 1993 \\
\hline Korea-Spain & 1994 \\
\hline Mexico-Netherlands & 1994 \\
\hline Mexico-United Kingdom & 1994 \\
\hline Mexico-Switzerland & 1994 \\
\hline Mexico-Spain & 1994 \\
\hline
\end{tabular}




\section{Table 8: Continued}

\begin{tabular}{lc}
\hline & \\
Country-Pair & Year in Force \\
\hline Italy-Netherlands & 1995 \\
Korea-Mexico & 1995 \\
Portugal-United States & 1995 \\
Japan-Mexico & 1996 \\
Mexico-Norway & 1997 \\
Denmark-Mexico & 1997 \\
Denmark-United Kingdom & 1997 \\
Korea-Portugal & 1997 \\
Mexico-Belgium & 1998 \\
Finland-Mexico & 1999 \\
Austria-Spain & 2000 \\
Netherlands-Portugal & 2001 \\
Canada-Portugal & 2001 \\
Mexico-Portugal & 2003 \\
Australia-Mexico & 2003 \\
Denmark-Portugal & 2003 \\
Portugal-Sweden & 2005 \\
Austria-Mexico & 2006 \\
New Zealand-Spain & 2007 \\
Austria-New Zealand & 2007 \\
Austria-Norway & 2007 \\
Mexico-New Zealand & \\
\hline
\end{tabular}

